\title{
7. PETROLOGY OF THE GABBRO-TROCTOLITE-PERIDOTITE COMPLEX FROM HESS DEEP, EQUATORIAL PACIFIC: IMPLICATIONS FOR MANTLE-MELT INTERACTION WITHIN THE OCEANIC LITHOSPHERE ${ }^{1}$
}

\author{
Shoji $\mathrm{Arai}^{2}$ and Kyoko Matsukage ${ }^{2}$
}

\begin{abstract}
Peridotites and related mafic plutonic rocks from Hess Deep in the equatorial Pacific (ODP Leg 147 Site 895) were examined in order to understand deep magmatic processes prevailing beneath the East Pacific Rise, a fast-spreading ridge system. Mantle harzburgite from Hess Deep is transitional to gabbro via dunite, troctolite, and olivine gabbro, in terms of petrography. The dunite-troctolite-olivine gabbro association can be interpreted as an interaction product between injected and stagnated melt and the harzburgite wall in the shallowest mantle. Troctolite and olivine gabbro are highly heterogeneous, for both their relative mineral ratio and mineral chemistry. Olivine-rich (i.e., plagioclase-poor) troctolite has the most Ti-enriched mineralogy, whereas the plagioclase-poor dunite associated with harzburgite has low-Ti mineralogy; the mineral chemical change possibly depends on the degree of melt stagnation. Chromian spinel is concentrated in some dunite and troctolite; a small chromitite pod was discovered. Primary hydrous minerals, $\mathrm{K}$ - and Na-phlogopites and pargasite, are usually present as inclusions in spinel from troctolite and chromitite, as commonly found in spinels from chromitites of both alpine and layered types. This indicates that the primary hydrous minerals can form in the oceanic mantle without slab-derived fluids.

The rocks examined are similar to constituents of the transition zone of some ophiolites, especially the Oman ophiolite, except for the podiform chromitites. The podiform chromitites of the ophiolites usually have high- $\mathrm{Cr} \#(\mathrm{Cr} /[\mathrm{Cr}+\mathrm{Al}]$ atomic ratio, 0.7 to 0.8 ) spinel, which has not been reported from ocean-floor rocks. The podiform chromitites could have formed in oceanic mantle conditions, but the typical podiform chromitites in ophiolites could not have been derived from the oceanic mantle.

Melt-mantle interaction possibly occurs in the mantle/crust boundary beneath the mid-ocean ridge axis, especially beneath a fast-spreading ridge axis with a high geothermal gradient. The interaction could form a spinel-olivine (Cr\#-Fo) compositional trend similar to that for relatively primitive MORB. The interaction between the high-pressure MORB and the wall harzburgite at the shallow upper mantle may contribute to the evolution of the MORB erupted on the ocean floor.
\end{abstract}

\section{INTRODUCTION}

Deep-sea drilling during Ocean Drilling Program (ODP) Leg 147 at Hess Deep, equatorial Pacific, had a two-fold purpose: to collect deep-seated rocks of the oceanic lithosphere formed at a fast-spreading ridge axis (East Pacific Rise) and to collect those exposed at a place other than an oceanic fracture zone. Petrological models for the oceanic lithosphere have been based mainly on rocks recovered from fracture zones of the slow-spreading ridge system, that is, of the Atlantic and Indian Oceans (e.g., Bonatti and Honnorez, 1976). Drilling Hess Deep is a good way to test ophiolite models because the petrological models have been based also on ophiolites (e.g., Nicolas, 1989).

Sinton and Detrick (1992) presented petrological models of "magma chambers" beneath mid-oceanic ridges with both fast- and slow-spreading rates based mainly on seismic tomography data. More recently, Cannat (1993) proposed a petrological model for the oceanic lithosphere from observations on rocks recovered from ocean floors. These models can be examined especially for deep pro-

'Mével, C., Gillis, K.M., Allan, J.F., and Meyer, P.S. (Eds.), 1996. Proc. ODP, Sci. Results, 147: College Station, TX (Ocean Drilling Program).

${ }^{2}$ Department of Earth Sciences, Faculty of Science, Kanazawa University, Kakumamachi, Kanazawa 920-11, Japan. ultrasa@icews I.ipc.kanazawa-u.ac.jp cesses by the petrology of the mafic-ultramafic rocks drilled and recovered from Hess Deep. Girardeau and Francheteau (1993) and Hekinian et al. (1993) have discussed the dredged samples. Hebert et al. (1983) and Cannat et al. (1990) reported a similar rock association (harzburgite, plagioclase dunite, troctolite, and olivine gabbro) for dredged rock fragments from the Garret Transform Fault on the East Pacific Rise. The rocks obtained by ocean-floor drilling during Leg 147 , however, have an advantage in that they represent much more continuous rock sections that provide for a much better understanding of deep processes in the oceanic lithosphere. In this chapter, the petrological characteristics of ultramafic and related plutonic rocks recovered from Site 895 of Leg 147 (Gillis, Mével, Allan, et al., 1993) are described in order to understand deep magmatic processes that form the oceanic lithosphere underneath the East Pacific Rise, a fast-spreading ridge system.

\section{GEOLOGICAL AND TECTONIC SETTING}

Hess Deep is located close to the Galapagos triple junction between the East Pacific Rise and the Cocos-Nazca propagating rift. Detailed descriptions of the tectonic setting are available from Francheteau et al. (1990) and Gillis, Mével, Allan, et al. (1993). Hess Deep is a kind of failed rift that formed at about $1 \mathrm{Ma}$ at the tip of the propagator. Serpentinite diapirism or other tectonism exposes deep- 
seated rocks formed beneath the East Pacific Rise (Francheteau et al., 1990). Dives by the submersible Nautile demonstrated that pillow basalt, dolerite, cumulate and noncumulate gabbros, dunite, and harzburgite are exposed there (Francheteau et al., 1990). The dolerite forms a dike complex, and a rock sequence similar to some ophiolites (e.g., Oman ophiolite) has been recognized by Francheteau et al. (1990, 1992). Drill Sites 894 and 895 were selected on an intrarift ridge; Site 894 on the summit and Site 895 on the southern flank of the ridge (Gillis, Mével, Allan, et al., 1993).

\section{PETROGRAPHY}

Six holes, 895A to 895F, were drilled; drilling at Holes 895D and $895 \mathrm{E}$ was especially successful because relatively long cores of 20 and $33 \mathrm{~m}$, respectively, were recovered (Gillis, Mével, Allan, et al., 1993). The two cores have contrasting lithologic characteristics; the core from Hole $895 \mathrm{D}$ is dominated by harzburgite whereas the core from Hole $895 \mathrm{E}$ is dominated by dunite (Fig. 1). The dunite tends to be associated with feldspathic rocks, gabbro, olivine gabbro, and troctolite (Fig. 1), which suggests a similarity to indigenous gabbro or pyroxenite dikes in ophiolites (e.g., Nicolas, 1989; Boudier et al., 1989). The noteworthy abundance of dunite at Hess Deep is similar to the mantle/crust transition zone of ophiolites (e.g., Nicolas and Prinzhofer, 1983; Nicolas, 1989). A similar rock assemblage was recovered from the Garret transform fault at the East Pacific Rise (Hebert et al., 1983; Cannat et al., 1990).

No igneous layered structures were observed in the cored rocks from Site 895 . Each lithology is irregularly distributed in the cores (Gillis, Mével, Allan, et al., 1993). Spinel trails or seams were observed in some dunites. Feldspathic plutonic rocks, gabbro, olivine gabbro, and troctolite are highly heterogeneous (Fig. 2), and gabbro is visually transitional to troctolite via olivine gabbro. Troctolite seems to be gradational to dunite and harzburgite via plagioclase dunite (Fig. 2). Harzburgite, on the other hand, appears to be abruptly transitional to plagioclase-free dunite.

A small chromitite pod or a rodlike chromitite was found in dunite from Hole $895 \mathrm{E}$ (Fig. 3). According to the shipboard observation by one of the authors (S.A.), a rodlike chromitite, less than $1 \mathrm{~cm}$ across, penetrates diagonally the cored dunite. Although small in size, the rodlike concentration of chromian spinel is similar to podiform chromitite in ophiolites (e.g., Thayer, 1964; Cassard et al., 1981; Lago et al., 1982). Some of the dunite reveals dissemination of small euhedral to subhedral chromian spinel. Troctolite typically has abundant anhedral chromian spinel (Fig. 2 and Pl. 1).

Wehrlite was also found, although the shipboard observation could not definitely confirm its presence (Gillis, Mével, Allan, et al., 1993). The possible wehrlite (e.g., Sample 147-895C-3R-1 [Piece 22, $130-133 \mathrm{~cm}])$ resembles harzburgite in hand specimen, but it has appreciable amounts of discrete grains of clinopyroxene instead of orthopyroxene (Pl. 1). This wehrlite is located just above a troctolite layer (Fig. 1A). We have not found orthopyroxene in these rocks in the laboratory.

\section{Harzburgite}

Harzburgite generally has a weak porphyroclastic to equigranular texture with orthopyroxene porphyroclasts (PI. 1, Fig. 1). Olivine and orthopyroxene are usually kinked. Some of the olivine is turbid in thin section and full of inclusion trails. Clinopyroxene, which in some places is altered to form tremolitic amphibole, is anhedral and usually associated with orthopyroxene porphyroclasts. Chromian spinel is anhedral (irregularly shaped), some is vermicular, and it is also commonly associated with orthopyroxene porphyroclasts (Pl. 1, Fig. 1). The color of the chromian spinel under a microscope is con-
A

Hole 895C

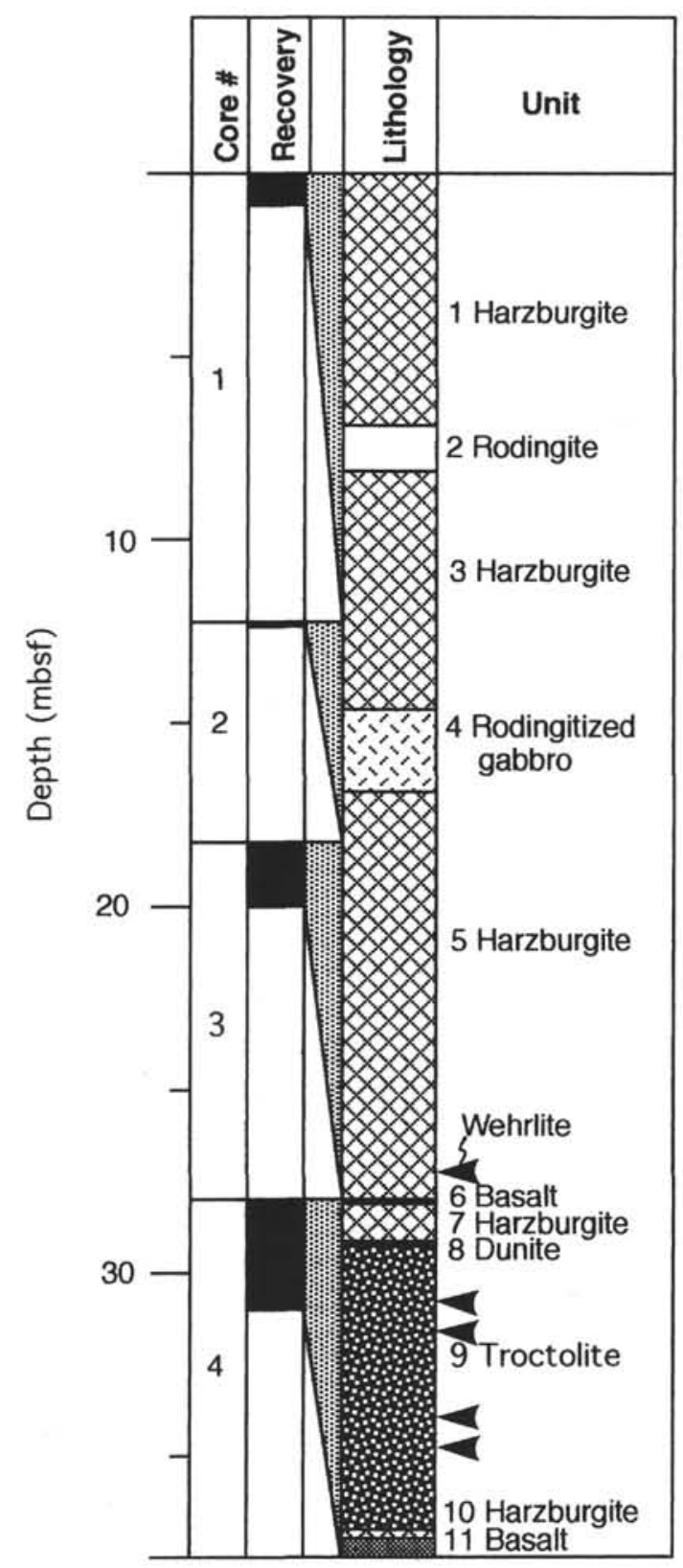

Figure 1. Schematic lithostratigraphic columns of drilled rocks modified from Gillis, Mével, Allan, et al. (1993). Positions of the samples examined in this study are shown by arrows. A. Hole 895 C. B. Hole 895 D. C. Hole 895 E. Note the close association of dunite with feldspathic plutonic rocks (troctolite and gabbros).

sistently brown, which indicates an intermediate $\mathrm{Cr} \#(=\mathrm{Cr} /[\mathrm{Cr}+\mathrm{Al}]$ atomic ratio). Petrographically, the Hess Deep harzburgite is similar to that in some ophiolites (e.g., Oman ophiolite).

\section{Dunite}

Dunite is variable in lithology. Plagioclase-free dunite is associated with harzburgite and plagioclase-bearing dunite is transitional to troctolite (Gillis, Mével, Allan, et al., 1993). Olivine in dunites is 
B

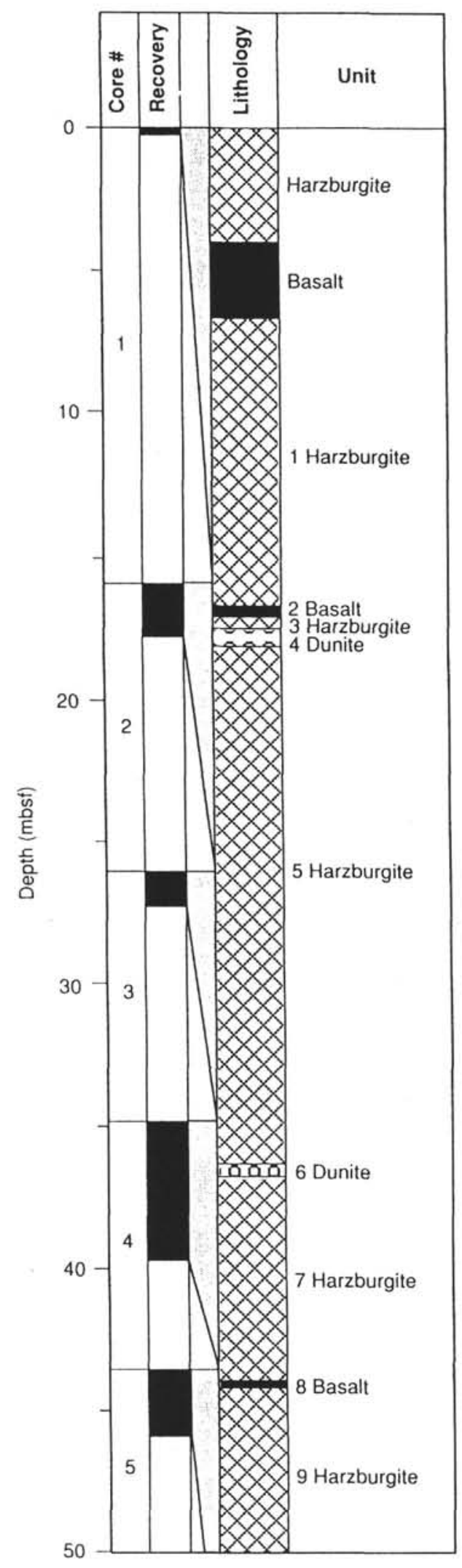

Hole 895D

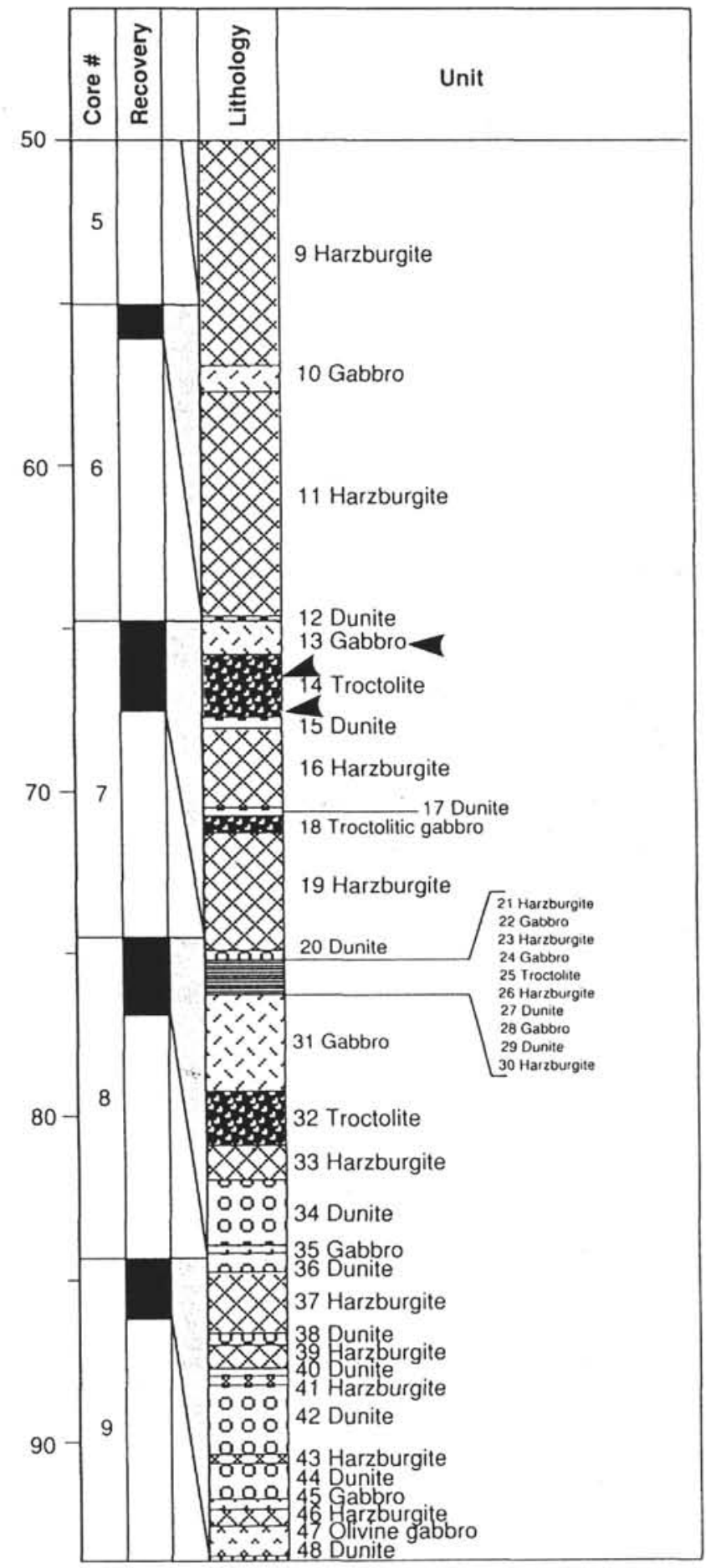

Figure 1 (continued). 
C

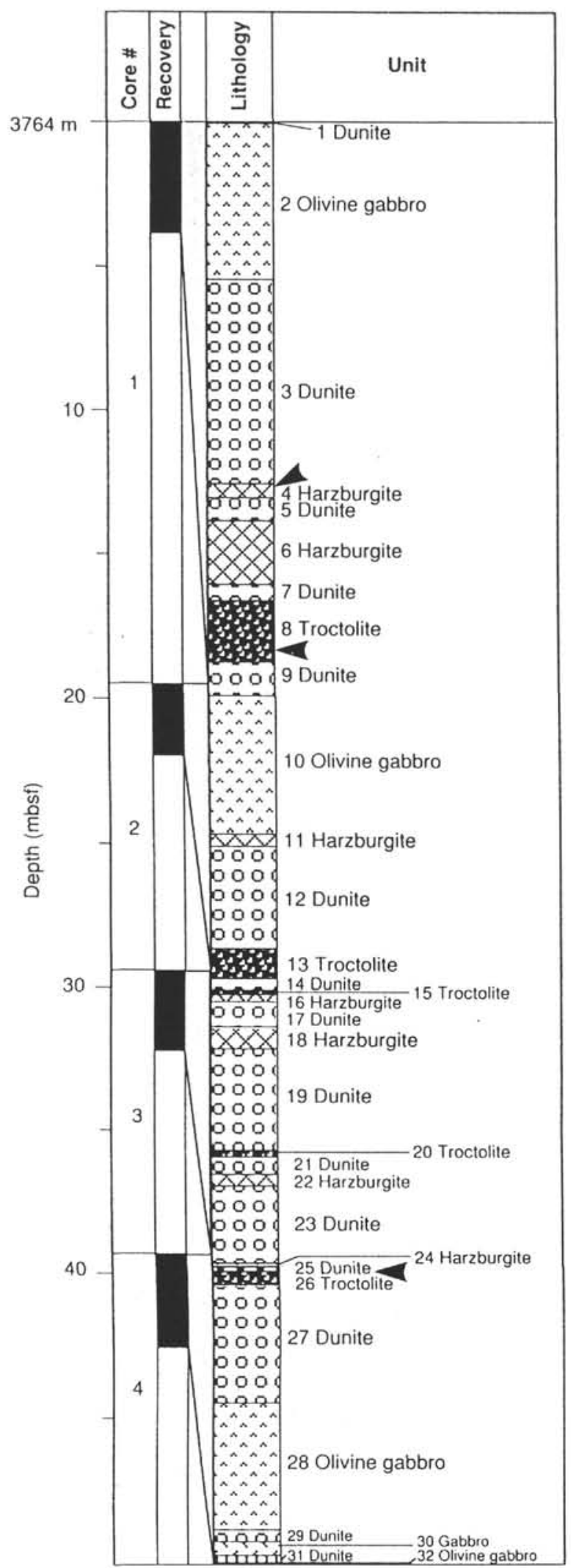

Hole 895E

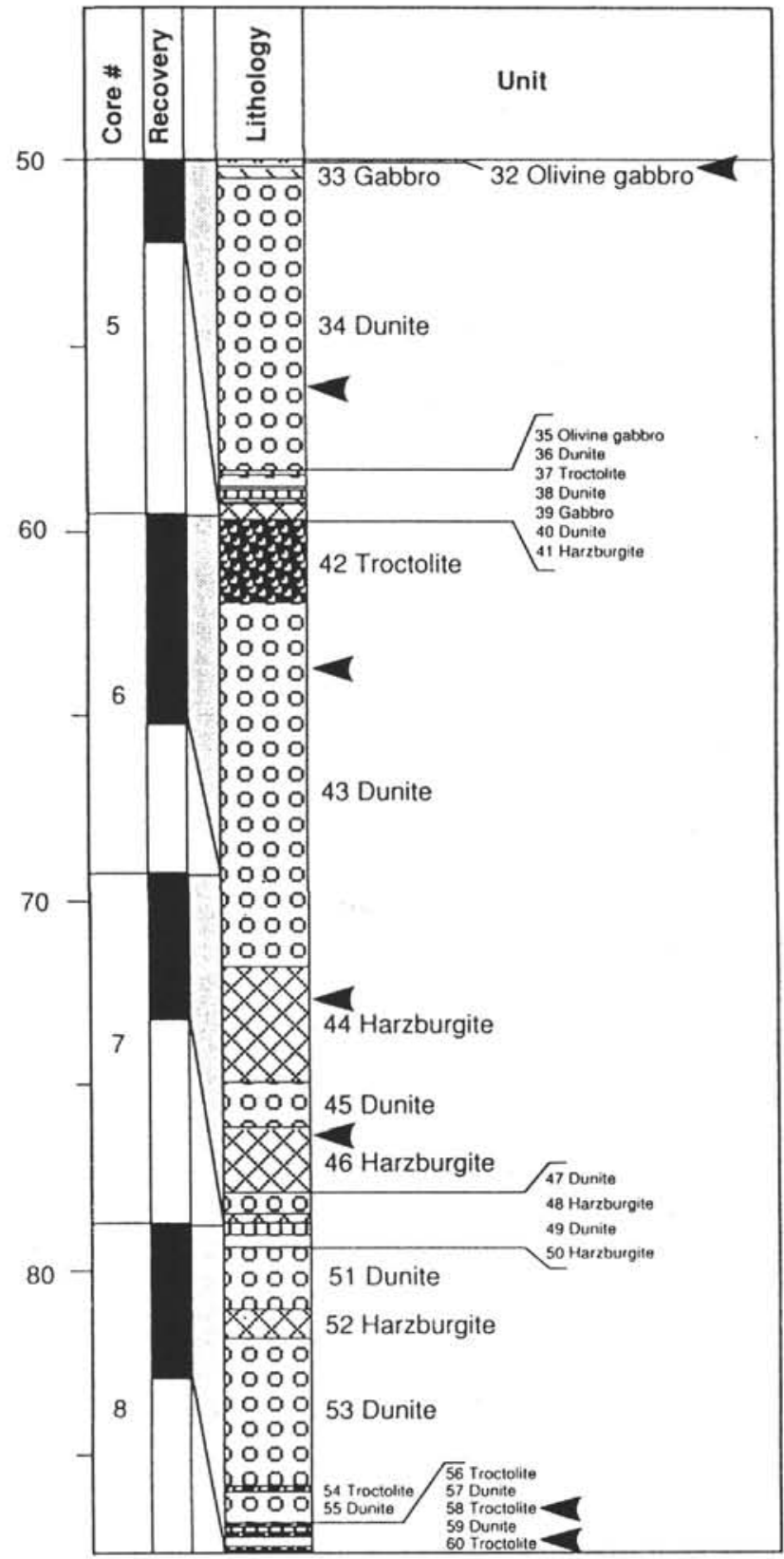

Figure 1 (continued). 


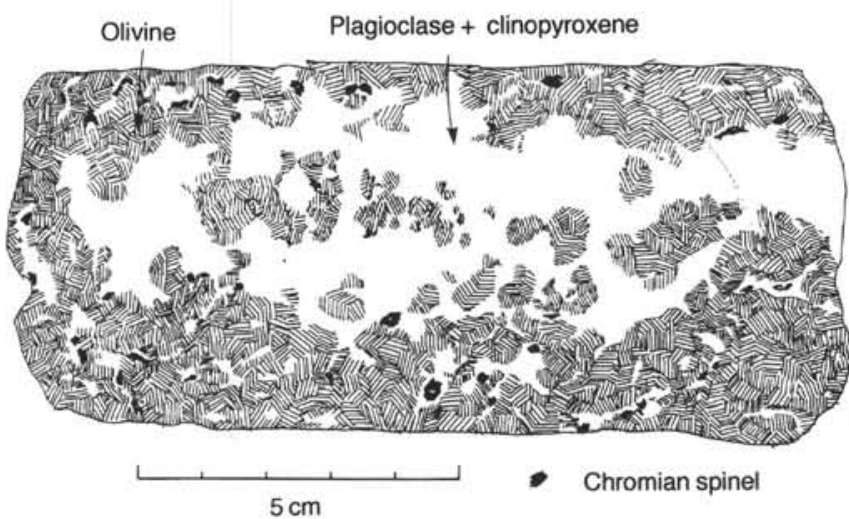

Figure 2. Sketch of a troctolite specimen (Section 147-895C-4R-2, 108-121 $\mathrm{cm})$. Note the heterogeneity and the concentration of spinel near olivine-rich zones.

kinked, although less commonly than in harzburgite, and is usually turbid owing to abundant inclusion trails (PI. 1, Fig. 2). Olivine in plagioclase-free dunite can be full of lamellar inclusions of some oxide, possibly spinel (Pl. 1, Fig. 3). The mode of occurrence of the lamellar inclusions is similar to that of chromian spinel lamellae in some alpine-type dunites (Arai, 1978). These textural characteristics are similar to those of transitional-zone dunite from some ophiolites. Chromian spinel in dunites is rounded in shape.

\section{Wehrlite}

This rock was originally described as harzburgite in Gillis, Mével, Allan, et al. (1993). The pyroxene grains are highly altered, but all relics are clinopyroxene (PI. 1, Fig. 4). Orthopyroxene could not be found under the microscope. Despite the abundance of clinopyroxene, the color of spinel (dark brown) does not indicate a lherzolitic (fertile) character and is similar to that of harzburgite spinel. We suspect that all the bastite-like pseudomorphs formed after clinopyroxene. The relic clinopyroxene is relatively coarse and free from deformation (Pl. 1, Fig. 4). Clinopyroxene commonly makes a symplectitic intergrowth with vermicular chromian spinel. Olivine in the wehrlite is full of inclusion trails, which is similar to olivine in dunite and troctolite and different from that in the ordinary harzburgite.

\section{Chromitite}

The minipod of chromitite in dunite is composed of large subhedral grains of chromian spinel, up to $5 \mathrm{~mm}$ across (Fig. 3 and Pl. 1, Fig. 5). The chromian spinel grains are characteristically full of minute mineral inclusions (Pl. 1, Fig. 5). The included minerals detected are Na-phlogopite, pargasite (or pargasitic hornblende), orthopyroxene, diopside, jadeite, and albite. It is noteworthy that these minerals are definitely primary because they are intact only where the enclosing spinel is fresh. Where the host spinel is altered or the inclusion is opened by cracks to the outside of the spinel grain, the inclusions are altered to chlorite, serpentine, or other hydrous minerals. The same minerals have been commonly documented as inclusions in chromian spinel of chromitites of both alpine (podiform) and layered types (e.g., Irvine, 1975; Johan et al., 1983; Talkington et al., 1984; Johan, 1986; Augé, 1987; McElduff and Stumpfl, 1991). The petrographic characteristics of the minipod of chromitite from Hess Deep are similar to those in the chromitites (e.g., Talkington et al., 1986; Augé, 1987).

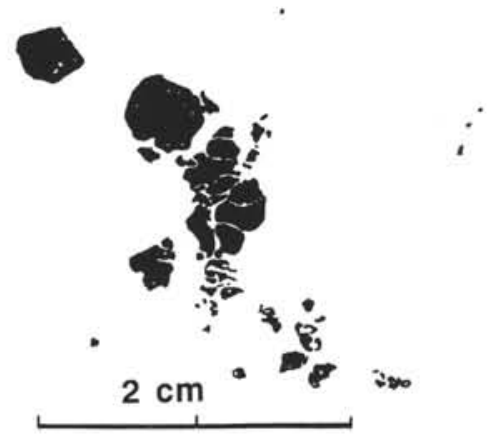

Figure 3. Sketch of the minipod of chromitite in dunite (Sample 147-895E$6 \mathrm{R}-2$ [Piece $2 \mathrm{E}, 77-80 \mathrm{~cm}$ ]). The cut surface is diagonal, at $60^{\circ}$, to the elongated rodlike pod, which is more complete in the archive half of the core.

\section{Troctolite}

Troctolite is composed of various amounts of olivine and plagioclase with small amounts of clinopyroxene and chromian spinel. The relative proportions of these minerals are highly variable even within a specimen (Fig. 2). Olivine is coarse and rounded in shape. Olivine is commonly turbid in thin section owing to the abundance of inclusion trails. Some of the olivine shows deformation features (PI. 1, Fig. 6), although plagioclase and clinopyroxene are not deformed. Plagioclase and clinopyroxene areanhedral, and some are interstitial to olivine. Clinopyroxene is usually diallage and poikilitically includes rounded olivine and euhedral plagioclase.

Chromian spinel is usually concentrated along the boundary between the olivine-rich (dunitic) part and the plagioclase- and clinopyroxene-rich (gabbroic) part (Fig. 2). Chromian spinel is rare within the leucocratic gabbroic part (Fig. 2). The morphology of chromian spinel varies depending on the mode of occurrence; chromian spinel is rounded in the olivine-rich part (PI. 1, Fig. 7) and anhedral in the olivine-poor part (Pl. 1, Fig. 8). Chromian spinel usually has rounded polymineralic inclusions (Pl. 1, Fig. 9), which consist mainly of Kand Na-phlogopites, pargasite (or pargasitic hornblende), diopsidic clinopyroxene, and orthopyroxene. The mode of occurrence of hydrous mineral inclusions in chromian spinel is similar to that in chromian spinel in chromitites (e.g., Talkington et al., 1986).

Orthopyroxene, kaersutite, and rutile were found almost exclusively in plagioclase-poor troctolite or plagioclase-bearing dunite (PI. 1, Figs. 10 and 11). Some of the orthopyroxene is rimmed by clinopyroxene, which suggests a reaction relation between orthopyroxene and a clinopyroxene-saturated liquid (PI. 1, Fig. 10). Orthopyroxene, highly anhedral, is also present in olivine-rich clots in plagioclaserich troctolite. Kaersutite is associated with rutile (PI. 1, Fig. 12).

\section{Olivine Gabbro}

Olivine gabbro is usually highly altered, and its primary petrographical characteristics can be difficult to discern. Olivine gabbro is usually very coarse grained and is also highly heterogenous; some irregularly shaped, olivine-rich (dunitic) patches are included in the leucocratic plagioclase- and clinopyroxene-rich part. Olivine gabbro may be the olivine-poor equivalent to the troctolite. The olivine in olivine gabbro is similar in appearance to that in troctolite. Chromian spinel is disseminated in and around some of the olivine-rich part. Some of the plagioclase is euhedral and it is usually poikilitically enclosed by clinopyroxene. Clinopyroxene is coarse and anhedral, usually poikilitically enclosing rounded olivine and euhedral plagioclase (PI. 1, Fig. 12). Small rounded chromian spinel is included in some clinopyroxene. 
Table 1. Selected microprobe analyses of minerals in olivine gabbro, troctolite, dunite, wehrlite, harzburgite, and the chromite pod from Site 895, Hess Deep.

\begin{tabular}{|c|c|c|c|c|c|c|c|c|c|c|c|c|c|}
\hline \multirow[b]{2}{*}{ Olivine gabbro } & \multicolumn{13}{|c|}{ 147-895B-IR-1 (Piece 5, 25-28 cm) } \\
\hline & oll & $\mathrm{ol} 2$ & $\begin{array}{c}\text { cpx1-2 } \\
\text { (rim) }\end{array}$ & $\begin{array}{l}\text { cpx } 1-4 \\
\text { (core) }\end{array}$ & $\begin{array}{c}\text { cpx } 1-5 \\
\text { (rim) }\end{array}$ & $\operatorname{cpx} 2$ & spl 1 & $\mathrm{sp} 2$ & sp3 & sp4 & sp5 & sp6 & $\mathrm{sp} 7$ \\
\hline $\mathrm{SiO}_{2}$ & 41.62 & 41.43 & 51.75 & 53.03 & 52.83 & 52.41 & 0.48 & 0.32 & 0.44 & 0.55 & 0.37 & 0.47 & 0.56 \\
\hline $\mathrm{TiO}_{2}$ & 0.12 & 0.03 & 0.16 & 0.28 & 0.44 & 0.49 & 1.15 & 1.65 & 1.88 & 1.43 & 2.57 & 2.84 & 2.38 \\
\hline $\mathrm{Al}_{2} \mathrm{O}_{3}$ & 0.16 & 0.03 & 3.68 & 3.18 & 3.29 & 3.27 & 20.94 & 18.40 & 18.35 & 19.59 & 16.94 & 12.80 & 18.57 \\
\hline $\mathrm{Cr}_{2} \mathrm{O}_{3}$ & 0.13 & 0.11 & 1.53 & 1.58 & 1.50 & 1.38 & 39.40 & 41.96 & 35.17 & 35.89 & 38.72 & 38.99 & 36.27 \\
\hline $\mathrm{FeO}^{*}$ & 11.76 & 11.83 & 3.16 & 3.71 & 3.92 & 3.77 & 27.31 & 29.49 & 37.40 & 35.10 & 33.59 & 38.49 & 36.94 \\
\hline $\mathrm{MnO}$ & 0.22 & 0.20 & 0.05 & 0.12 & 0.09 & 0.15 & 0.54 & 0.57 & 0.63 & 0.52 & 0.46 & 0.49 & 0.60 \\
\hline $\mathrm{MgO}$ & 48.71 & 48.04 & 17.42 & 18.08 & 17.01 & 16.37 & 9.01 & 8.21 & 6.52 & 6.38 & 7.61 & 5.72 & 6.38 \\
\hline $\mathrm{CaO}$ & 0.13 & 0.12 & 21.59 & 21.26 & 21.59 & 22.67 & 0.28 & 0.14 & 0.19 & 0.36 & 0.18 & 0.19 & 0.11 \\
\hline $\mathrm{Na}_{2} \mathrm{O}$ & 0.00 & 0.00 & 0.13 & 0.00 & 0.00 & 0.00 & 0.00 & 0.00 & 0.00 & 0.00 & 0.00 & 0.00 & 0.00 \\
\hline $\mathrm{K}, \mathrm{O}$ & 0.04 & 0.05 & 0.00 & 0.00 & 0.00 & 0.00 & 0.06 & 0.00 & 0.01 & 0.03 & 0.07 & 0.04 & 0.00 \\
\hline $\mathrm{P}_{\mathrm{O}}$ & 0.19 & 0.10 & 0.28 & 0.05 & 0.29 & 0.17 & 0.00 & 0.00 & 0.10 & 0.00 & 0.00 & 0.04 & 0.08 \\
\hline $\mathrm{NiO}$ & 0.24 & 0.30 & 0.02 & 0.15 & 0.11 & 0.12 & 0.14 & 0.14 & 0.34 & 0.08 & 0.19 & 0.25 & 0.33 \\
\hline Total & 103.32 & 102.24 & 99.77 & 101.44 & 101.07 & 100.8 & 99.31 & 100.88 & 101.03 & 99.93 & 100.7 & 100.32 & 102.22 \\
\hline $\mathrm{O}$ & 4 & 4 & 6 & 6 & 6 & 6 & 4 & 4 & 4 & 4 & 4 & 4 & 4 \\
\hline $\mathrm{Si}$ & 0.995 & 1.002 & 1.886 & 1.903 & 1.904 & 1.901 & 0.015 & 0.010 & 0.014 & 0.018 & 0.012 & 0.016 & 0.018 \\
\hline $\mathrm{Ti}$ & 0.002 & 0.000 & 0.004 & 0.007 & 0.012 & 0.013 & 0.028 & 0.040 & 0.047 & 0.035 & 0.064 & 0.073 & 0.058 \\
\hline Al & 0.004 & 0.000 & 0.158 & 0.134 & 0.139 & 0.139 & 0.798 & 0.704 & 0.720 & 0.768 & 0.661 & 0.521 & 0.717 \\
\hline $\mathrm{Cr}$ & 0.002 & 0.002 & 0.044 & 0.044 & 0.042 & 0.039 & 1.007 & 1.077 & 0.925 & 0.943 & 1.014 & 1.064 & 0.939 \\
\hline $\mathrm{Fe}^{*}$ & 0.235 & 0.239 & 0.096 & 0.111 & 0.118 & 0.114 & 0.738 & 0.801 & 1.041 & 0.976 & 0.931 & 1.112 & 1.012 \\
\hline Mn & 0.004 & 0.004 & 0.001 & 0.003 & 0.002 & 0.004 & 0.014 & 0.015 & 0.018 & 0.014 & 0.013 & 0.014 & 0.016 \\
\hline $\mathrm{Mg}$ & 1.735 & 1.731 & 0.946 & 0.966 & 0.913 & 0.884 & 0.434 & 0.397 & 0.323 & 0.316 & 0.375 & 0.294 & 0.312 \\
\hline $\mathrm{Ca}$ & 0.003 & 0.003 & 0.842 & 0.817 & 0.833 & 0.880 & 0.009 & 0.005 & 0.007 & 0.013 & 0.006 & 0.007 & 0.003 \\
\hline $\mathrm{Na}$ & 0.000 & 0.000 & 0.010 & 0.000 & 0.000 & 0.000 & 0.000 & 0.000 & 0.000 & 0.000 & 0.000 & 0.000 & 0.000 \\
\hline K & 0.001 & 0.001 & 0.000 & 0.000 & 0.000 & 0.000 & 0.002 & 0.000 & 0.000 & 0.001 & 0.003 & 0.001 & 0.000 \\
\hline$\ddot{p}$ & 0.004 & 0.002 & 0.008 & 0.001 & 0.008 & 0.005 & 0.000 & 0.000 & 0.002 & 0.000 & 0.000 & 0.001 & 0.002 \\
\hline $\mathrm{Ni}$ & 0.004 & 0.005 & 0.000 & 0.004 & 0.003 & 0.003 & 0.003 & 0.003 & 0.009 & 0.002 & 0.005 & 0.007 & 0.008 \\
\hline Total & 2.993 & 2.993 & 4.000 & 3.996 & 3.979 & 3.987 & 3.054 & 3.057 & 3.111 & 3.090 & 3.087 & 3.115 & 3.091 \\
\hline $\mathrm{Fe}^{2+}$ & 0.235 & 0.239 & 0.096 & 0.111 & 0.118 & 0.114 & 0.540 & 0.569 & 0.649 & 0.662 & 0.576 & 0.654 & 0.643 \\
\hline $\mathrm{Fe}^{3+}$ & & & & & & & 0.142 & 0.152 & 0.298 & 0.244 & 0.227 & 0.312 & 0.253 \\
\hline $\mathrm{Mg \#}$ & 0.881 & 0.879 & 0.908 & 0.897 & 0.886 & 0.886 & 0.446 & 0.411 & 0.332 & 0.323 & 0.394 & 0.310 & 0.327 \\
\hline $\mathrm{Cr} /(\mathrm{Cr}+\mathrm{Al})$ & & & & & & & 0.558 & 0.605 & 0.562 & 0.551 & 0.605 & 0.671 & 0.567 \\
\hline $\mathrm{Ca} /(\mathrm{Ca}+\mathrm{Na})$ & & & & & & & & & & & & & \\
\hline $\mathrm{Fe}^{2+} /\left(\mathrm{Cr}+\mathrm{Al}+\mathrm{Fe}^{4+}\right)$ & & & & & & & 0.073 & 0.078 & 0.154 & 0.125 & 0.119 & 0.164 & 0.133 \\
\hline $\mathrm{Al} /\left(\mathrm{Cr}+\mathrm{Al}+\mathrm{Fe}^{3-}\right)$ & & & & & & & 0.410 & 0.364 & 0.370 & 0.393 & 0.348 & 0.275 & 0.376 \\
\hline $\mathrm{Cr} /\left(\mathrm{Cr}+\mathrm{Al}+\mathrm{Fe}^{3+}\right)$ & & & & & & & 0.517 & 0.557 & 0.476 & 0.482 & 0.533 & 0.561 & 0.492 \\
\hline
\end{tabular}

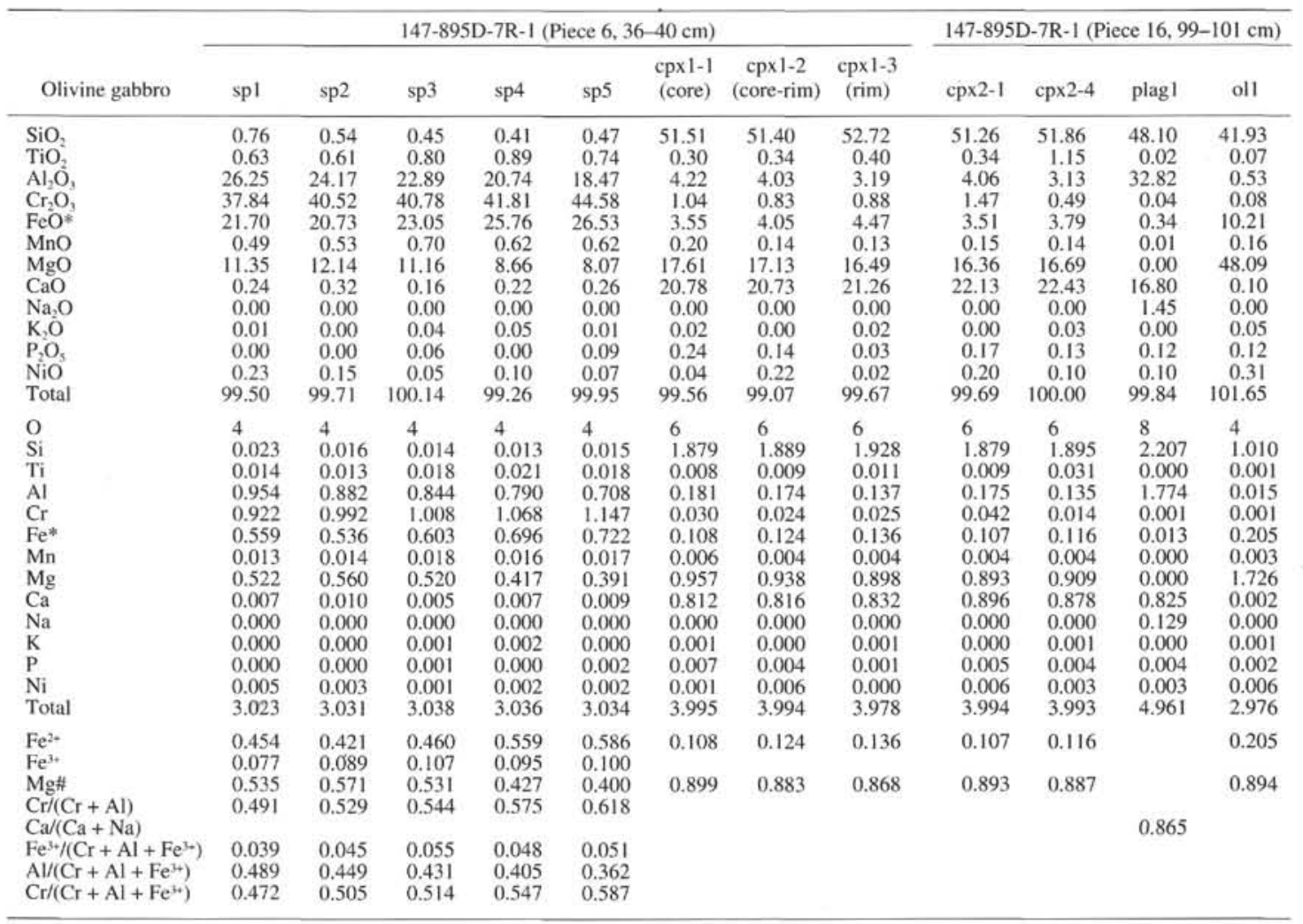


Table 1 (continued).

\begin{tabular}{|c|c|c|c|c|c|c|c|c|c|c|c|c|c|}
\hline \multirow[b]{2}{*}{ Olivine gabbro } & \multicolumn{4}{|c|}{$\begin{array}{l}\text { 147-895D-7R-1 (Piece 16,99-101 cm) } \\
\text { (continued) }\end{array}$} & \multicolumn{4}{|c|}{ 147-895E-4R-1 (Piece 5, 24-26 cm) } & \multicolumn{5}{|c|}{ 147-895E-5R-1 (Piece 9, 45-47 cm) } \\
\hline & spl 1 & sp2 & plagl & plag2 & oll & spl & $\mathrm{sp} 2$ & plag 1 & oll & spl & $\mathrm{sp} 2$ & cpx1 & plag 1 \\
\hline $\mathrm{SiO}_{2}$ & 0.36 & 0.26 & 47.54 & 47.35 & 41.73 & 0.14 & 0.24 & 46.51 & 40.95 & 0.27 & 0.255 & 1.68 & 47.32 \\
\hline $\mathrm{TiO}_{2}$ & 2.05 & 0.45 & 0.05 & 0.09 & 0.11 & 0.87 & 0.40 & 0.14 & 0.01 & 0.73 & 1.42 & 0.39 & 0.07 \\
\hline $\mathrm{Al}_{2} \mathrm{O}_{3}$ & 20.30 & 32.46 & 32.81 & 33.24 & 0.21 & 22.73 & 28.42 & 33.34 & 0.37 & 26.38 & 17.80 & 4.56 & 33.81 \\
\hline $\mathrm{Cr}_{2} \mathrm{O}_{3}$ & 42.77 & 34.59 & 0.05 & 0.14 & 0.00 & 40.22 & 36.90 & 0.02 & 0.08 & 36.79 & 40.84 & 1.43 & 0.15 \\
\hline $\mathrm{FeO}^{*}$ & 21.83 & 16.01 & 0.30 & 0.27 & 10.59 & 23.54 & 18.46 & 0.76 & 13.54 & 22.44 & 30.53 & 3.81 & 0.20 \\
\hline $\mathrm{MnO}$ & 0.21 & 0.00 & 0.08 & 0.02 & 0.15 & 0.15 & 0.00 & 0.02 & 0.35 & 0.24 & 0.23 & 0.21 & 0.04 \\
\hline $\mathrm{MgO}$ & 11.56 & 15.49 & 0.00 & 0.00 & 47.15 & 11.41 & 13.80 & 0.34 & 45.79 & 12.75 & 8.37 & 17.0 & 30.00 \\
\hline $\mathrm{CaO}$ & 0.18 & 0.23 & 17.19 & 17.11 & 0.10 & 0.11 & 0.11 & 17.88 & 0.18 & 0.13 & 0.17 & 21.08 & 17.54 \\
\hline $\mathrm{Na}_{2} \mathrm{O}$ & 0.00 & 0.00 & 1.00 & 1.65 & 0.25 & 0.00 & 0.00 & 0.90 & 0.00 & 0.00 & 0.00 & 0.07 & 1.13 \\
\hline $\mathrm{K}_{2} \mathrm{O}$ & 0.03 & 0.04 & 0.04 & 0.01 & 0.06 & 0.08 & 0.00 & 0.04 & 0.05 & 0.02 & 0.08 & 0.01 & 0.02 \\
\hline $\mathrm{P}_{2} \mathrm{O}_{5}$ & 0.00 & 0.08 & 0.19 & 0.11 & 0.00 & 0.00 & 0.04 & 0.00 & 0.00 & 0.12 & 0.00 & 0.16 & 0.04 \\
\hline $\mathrm{NiO}$ & 0.14 & 0.01 & 0.07 & 0.09 & 0.29 & 0.16 & 0.13 & 0.05 & 0.22 & 0.09 & 0.09 & 0.02 & 0.00 \\
\hline Total & 99.43 & 99.62 & 99.32 & 100.08 & 100.69 & 99.46 & 98.54 & 100.05 & 101.54 & 99.96 & 99.78 & 100.45 & 100.32 \\
\hline $\mathrm{O}$ & 4 & 4 & 8 & 8 & 4 & 4 & 4 & 8 & 4 & 4 & 4 & 6 & 8 \\
\hline $\mathrm{Si}$ & 0.011 & 0.007 & 2.192 & 2.173 & 1.018 & 0.004 & 0.007 & 2.144 & 1.005 & 0.008 & 0.008 & $1: 873$ & 2.164 \\
\hline $\mathrm{Ti}$ & 0.048 & 0.010 & 0.001 & 0.003 & 0.002 & 0.020 & 0.009 & 0.004 & 0.000 & 0.0 & 160.03 & 50.01 & 00.002 \\
\hline $\mathrm{Al}$ & 0.757 & 1.120 & 1.783 & 1.797 & 0.006 & 0.846 & 1.019 & 1.811 & 0.010 & 0.95 & 40.69 & 30.19 & 51.822 \\
\hline $\mathrm{Cr}$ & 1.069 & 0.800 & 0.001 & 0.005 & 0.000 & 1.004 & 0.887 & 0.000 & 0.001 & 0.892 & 1.066 & 0.0411 & 0.005 \\
\hline $\mathrm{Fe}^{*}$ & 0.577 & 0.392 & 0.011 & 0.010 & 0.216 & 0.622 & 0.469 & 0.029 & 0.277 & 0.575 & 0.843 & 0.115 & 0.007 \\
\hline $\mathrm{Mn}$ & 0.005 & 0.000 & 0.003 & 0.001 & 0.003 & 0.004 & 0.000 & 0.000 & 0.007 & 0.006 & 0.006 & 0.000 & 0.001 \\
\hline $\mathrm{Mg}$ & 0.545 & 0.676 & 0.000 & 0.000 & 1.714 & 0.537 & 0.626 & 0.023 & 1.674 & 0.582 & 0.412 & 0.919 & 0.000 \\
\hline $\mathrm{Ca}$ & 0.006 & 0.007 & 0.849 & 0.841 & 0.002 & 0.004 & 0.003 & 0.883 & 0.004 & 0.004 & 0.006 & 0.818 & 0.859 \\
\hline $\mathrm{Na}$ & 0.000 & 0.000 & 0.090 & 0.146 & 0.012 & 0.000 & 0.000 & 0.080 & 0.000 & 0.000 & 0.000 & 0.005 & 0.100 \\
\hline K & 0.001 & 0.001 & 0.002 & 0.000 & 0.001 & 0.003 & 0.000 & 0.001 & 0.001 & 0.000 & 0.003 & 0.000 & 0.001 \\
\hline P & 0.000 & 0.002 & 0.007 & 0.004 & 0.000 & 0.000 & 0.001 & 0.000 & 0.000 & 0.003 & 0.000 & 0.005 & 0.001 \\
\hline $\mathrm{Ni}$ & 0.003 & 0.000 & 0.002 & 0.003 & 0.005 & 0.004 & 0.003 & 0.001 & 0.004 & 0.002 & 0.002 & 0.000 & 0.000 \\
\hline Total & 3.027 & 3.019 & 4.947 & 4.988 & 2.983 & 3.051 & 3.028 & 4.976 & 2.988 & 3.047 & 3.078 & 3.992 & 4.967 \\
\hline $\mathrm{Fe}^{2+}$ & 0.406 & 0.313 & & & 0.216 & 0.453 & 0.368 & & 0.277 & 0.408 & 0.569 & 0.115 & \\
\hline $\mathrm{Fe}^{2+}$ & 0.075 & 0.059 & & & & 0.129 & 0.083 & & & 0.135 & 0.204 & & \\
\hline $\mathrm{Mg \#}$ & 0.573 & 0.683 & & & 0.888 & 0.543 & 0.630 & & 0.858 & 0.588 & 0.420 & 0.889 & \\
\hline $\mathrm{Cr} /(\mathrm{Cr}+\mathrm{Al})$ & 0.585 & 0.417 & 0.904 & 0.852 & & 0.543 & 0.465 & & & 0.483 & 0.606 & & \\
\hline $\mathrm{Ca} /(\mathrm{Ca}+\mathrm{Na})$ & & & & & & & & 0.917 & & & & & 0.896 \\
\hline $\mathrm{Fe}^{3+} /\left(\mathrm{Cr}+\mathrm{Al}+\mathrm{Fe}^{3+}\right)$ & 0.040 & 0.030 & & & & 0.065 & 0.042 & & & 0.068 & 0.104 & & \\
\hline $\mathrm{Al} /\left(\mathrm{Cr}+\mathrm{Al}+\mathrm{Fe}^{3+}\right)$ & 0.398 & 0.566 & & & & 0.427 & 0.512 & & & 0.482 & 0.353 & & \\
\hline $\mathrm{Cr} /\left(\mathrm{Cr}+\mathrm{Al}+\mathrm{Fe}^{3+}\right)$ & 0.562 & 0.404 & & & & 0.507 & 0.446 & & & 0.450 & 0.543 & & \\
\hline
\end{tabular}

\section{MINERAL CHEMISTRY}

Minerals were analyzed by an Akashi Alpha30 SEM-EDAX system with an energy-dispersive spectrometer at Kanazawa University. The detection limit is approximately $0.1 \mathrm{wt} \%$ for major oxides except for $\mathrm{Na}_{2} \mathrm{O}$, for which the detection limit is approximately $0.3 \mathrm{wt} \%$. The reproducibility of the data is sufficiently good for major elements. The $\mathrm{Mg} \#(=\mathrm{Mg} /[\mathrm{Mg}+$ total iron $]$ atomic ratio) of silicates and the $\mathrm{Cr} \#$ were determined with special care; these ratios are reproducible to about $\pm 0.2 \%$ and about $\pm 0.8 \%$, respectively, on repeated runs. Selected analyses are listed in Tables $1-4$. The mineral chemistry for the discrete minerals is described in the following sections. The mineral inclusions in chromian spinel are described separately. The cation ratios of spinel were calculated assuming spinel stoichiometry after subtracting all $\mathrm{Ti}$ as ulvospinel molecules $\left(\mathrm{Fe}_{2} \mathrm{TiO}_{4}\right)$.

\section{Olivine}

The olivine chemistry varies depending on lithology from $\mathrm{Fo}_{91}$ in harzburgite through dunite, wehrlite, and troctolite to $\mathrm{Fo}_{86}$ in olivine gabbro (Fig. 4). In troctolitic rocks olivine tends to be less magnesian in plagioclase-poor rocks (or parts) than in plagioclase-rich ones (or parts). For example, olivine in one plagioclase-poor troctolite (Sample 147-895C-4R-2 [Piece 6B, 110-114 cm]), which has orthopyroxene, rutile, and Ti-rich spinel, has the lowest Fo value of 88 (Fig. 4).

\section{Orthopyroxene}

Orthopyroxene in harzburgite is magnesian with a $\mathrm{Mg} \#$ of about 0.91 (Table 3). $\mathrm{Al}_{2} \mathrm{O}_{3}$ and $\mathrm{Cr}_{2} \mathrm{O}_{3}$ contents are 2 to $3 \mathrm{wt} \%$ and 0.8 to $1.0 \mathrm{wt} \%$, respectively. Orthopyroxene in plagioclase-poor troctolite is less magnesian, with a $\mathrm{Mg} \#$ from 0.89 to 0.91 (mostly about 0.89 ).
$\mathrm{Al}_{2} \mathrm{O}_{3}$ and $\mathrm{Cr}_{2} \mathrm{O}_{3}$ contents are 2 to $3 \mathrm{wt} \%$ and 0.6 to $0.7 \mathrm{wt} \%$, respectively (Table 3 ).

\section{Clinopyroxene}

The Mg\# of clinopyroxene varies partly owing to subsolidus MgFe redistribution, depending on the relative amount of clinopyroxene (e.g., Arai et al., 1988). Clinopyroxenes from harzburgite and wehrlite have the highest $\mathrm{Mg} \#$ (Fig. 5). $\mathrm{TiO}_{2}$ contents in clinopyroxene are highly variable from almost none (harzburgite) to $2 \mathrm{wt} \%$ (troctolite) (Fig. 5). The $\mathrm{TiO}_{2}$ content of clinopyroxene demonstrates an almost parallel variation with that in chromian spinel, as shown later. It is noteworthy that the clinopyroxene in olivine gabbro has a lower $\mathrm{Ti}$ content than clinopyroxene in troctolite has (Fig. 5). As for chromian spinel, clinopyroxene in the olivine-rich troctolite, which has orthopyroxene and rutile, tends to have a higher $\mathrm{TiO}_{2}$ content than in the olivine-poor troctolites (Fig. 5). Clinopyroxene in troctolite also shows an intragrain chemical heterogeneity for $\mathrm{Ti}$; the rim, especially the peripheral part of strongly anhedral crystals, is distinctly higher in Ti than the core (Fig. 5). The chemical zoning is, however, more complicated in the texturally heterogeneous troctolite; a compositional gradient can be detected sporadically in a large crystal, from a rim in contact with a plagioclase-rich pool $\left(\mathrm{TiO}_{2}=0.30 \mathrm{wt} \% ; \mathrm{Mg} \#=\right.$ $0.89)$ to another rim in contact with an olivine-rich clot $\left(\mathrm{TiO}_{2}=0.72\right.$ $\mathrm{wt} \% ; \mathrm{Mg} \#=0.91)$ via the core $\left(\mathrm{TiO}_{2}=0.35 \mathrm{wt} \% ; \mathrm{Mg} \#=0.90\right)$, which indicates that it crystallized under a strong chemical gradient within the melt (Fig. 5).

$\mathrm{Ti}-\mathrm{Cr}$ relationships for clinopyroxenes are also noteworthy. The $\mathrm{Cr}_{2} \mathrm{O}_{3}$ contents of clinopyroxene are remarkably constant, within the range 1.0 to $1.3 \mathrm{wt} \%$, in spite of the wide variation of the $\mathrm{TiO}_{2}$ content (Fig. 6). This contrasts with an igneous trend, a strong negative correlation between $\mathrm{Ti}$ and $\mathrm{Cr}$ contents in clinopyroxene, such as that for Bushveld cumulates (e.g., Atkins, 1969). 
Table 2. Selected microprobe analyses of minerals in troctolite from Site 895, Hess Deep.

147-895C-4R-2 (Piece 1B, 36-41 cm)

\begin{tabular}{|c|c|c|c|c|c|c|c|c|c|c|c|c|c|}
\hline Troctolite & oll & $\mathrm{ol} 2$ & spl & sp2 & sp3 & sp4 & cpxl & cp $x 2$ & cp $\times 3$ & $\begin{array}{l}\text { epx4-1 } \\
\text { (core) }\end{array}$ & срх4-2 & cpx 5 & cpx6 \\
\hline $\mathrm{SiO}_{2}$ & 41.04 & 40.95 & 0.48 & 0.41 & 0.40 & 0.54 & 56.91 & 51.63 & 50.92 & 52.08 & 50.92 & 50.36 & 52.40 \\
\hline $\mathrm{TiO}_{2}^{2}$ & 0.02 & 0.10 & 2.04 & 2.65 & 2.30 & 1.77 & 0.41 & 1.90 & 1.72 & 0.98 & 1.50 & 1.15 & 1.08 \\
\hline $\mathrm{Al}_{2} \mathrm{O}_{3}$ & 0.13 & 0.12 & 17.15 & 18.86 & 19.83 & 19.03 & 2.88 & 3.80 & 3.84 & 3.16 & 3.68 & 3.82 & 2.88 \\
\hline $\mathrm{Cr}_{2} \mathrm{O}_{3}$ & 0.00 & 0.10 & 39.05 & 38.29 & 36.49 & 37.21 & 0.55 & 1.18 & 1.22 & 1.06 & 1.09 & 1.21 & 1.05 \\
\hline $\mathrm{FeO}^{*}$ & 11.31 & 12.00 & 32.33 & 29.10 & 30.76 & 30.86 & 3.10 & 3.16 & 2.90 & 2.81 & 3.22 & 3.92 & 3.59 \\
\hline $\mathrm{MnO}$ & 0.06 & 0.27 & 0.59 & 0.58 & 0.79 & 0.54 & 0.06 & 0.16 & 0.08 & 0.09 & 0.07 & 0.14 & 0.21 \\
\hline $\mathrm{MgO}$ & 47.77 & 47.86 & 8.00 & 10.54 & 9.57 & 8.71 & 22.67 & 16.20 & 15.64 & 16.65 & 16.33 & 19.79 & 16.82 \\
\hline $\mathrm{CaO}$ & 0.05 & 0.12 & 0.12 & 0.12 & 0.12 & 0.13 & 13.21 & 22.48 & 22.55 & 22.05 & 22.54 & 19.13 & 22.10 \\
\hline $\mathrm{Na}_{2} \mathrm{O}$ & 0.00 & 0.00 & 0.00 & 0.00 & 0.00 & 0.00 & 0.00 & 0.00 & 0.00 & 0.00 & 0.00 & 0.00 & 0.00 \\
\hline $\mathrm{K}_{2} \mathrm{O}$ & 0.01 & 0.06 & 0.01 & 0.00 & 0.01 & 0.01 & 0.02 & 0.00 & 0.00 & 0.00 & 0.00 & 0.00 & 0.00 \\
\hline $\mathrm{P}_{2} \mathrm{O}_{5}$ & 0.15 & 0.09 & 0.07 & 0.16 & 0.09 & 0.32 & 0.23 & 0.13 & 0.19 & 0.23 & 0.02 & 0.27 & 0.00 \\
\hline $\mathrm{NiO}$ & 0.35 & 0.35 & 0.31 & 0.18 & 0.24 & 0.31 & 0.05 & 0.01 & 0.06 & 0.00 & 0.03 & 0.21 & 0.05 \\
\hline Total & 100.89 & 102.02 & 100.15 & 100.89 & 100.60 & 99.43 & 100.14 & 100.65 & 99.12 & 99.11 & 99.40 & 100.00 & 100.18 \\
\hline $\mathrm{O}$ & 4 & 4 & 4 & 4 & 4 & 4 & 6 & 6 & 6 & 6 & 6 & 6 & 6 \\
\hline $\mathrm{Si}$ & 1.002 & 1.005 & 0.015 & 0.013 & 0.013 & 0.017 & 1.992 & 1.871 & 1.873 & 1.906 & 1.872 & 1.833 & 1.908 \\
\hline $\mathrm{Ti}$ & 0.000 & 0.001 & 0.050 & 0.063 & 0.056 & 0.043 & 0.010 & 0.051 & 0.047 & 0.027 & 0.041 & 0.031 & 0.029 \\
\hline $\mathrm{Al}$ & 0.003 & 0.003 & 0.670 & 0.713 & 0.755 & 0.738 & 0.119 & 0.162 & 0.166 & 0.136 & 0.159 & 0.164 & 0.124 \\
\hline $\mathrm{Cr}$ & 0.000 & 0.001 & 1.023 & 0.970 & 0.931 & 0.968 & 0.015 & 0.033 & 0.035 & 0.030 & 0.031 & 0.035 & 0.030 \\
\hline $\mathrm{Fe}^{*}$ & 0.231 & 0.241 & 0.896 & 0.780 & 0.831 & 0.849 & 0.091 & 0.095 & 0.089 & 0.086 & 0.099 & 0.119 & 0.109 \\
\hline $\mathrm{Mn}$ & 0.001 & 0.005 & 0.016 & 0.015 & 0.021 & 0.015 & 0.001 & 0.004 & 0.002 & 0.002 & 0.002 & 0.004 & 0.006 \\
\hline $\mathrm{Mg}$ & 1.739 & 1.715 & 0.395 & 0.504 & 0.460 & 0.427 & 1.182 & 0.874 & 0.856 & 0.908 & 0.984 & 1.073 & 0.913 \\
\hline $\mathrm{Ca}$ & 0.001 & 0.003 & 0.004 & 0.004 & 0.004 & 0.004 & 0.495 & 0.872 & 0.888 & 0.864 & 0.887 & 0.746 & 0.862 \\
\hline $\mathrm{Na}$ & 0.000 & 0.000 & 0.000 & 0.000 & 0.000 & 0.000 & 0.000 & 0.000 & 0.000 & 0.000 & 0.000 & 0.000 & 0.000 \\
\hline K & 0.000 & 0.001 & 0.000 & 0.000 & 0.000 & 0.000 & 0.001 & 0.000 & 0.000 & 0.000 & 0.000 & 0.000 & 0.000 \\
\hline P & 0.003 & 0.001 & 0.001 & 0.004 & 0.002 & 0.003 & 0.007 & 0.004 & 0.006 & 0.007 & 0.000 & 0.008 & 0.000 \\
\hline $\mathrm{Ni}$ & 0.007 & 0.006 & 0.008 & 0.004 & 0.006 & 0.008 & 0.001 & 0.000 & 0.001 & 0.000 & 0.001 & 0.006 & 0.001 \\
\hline Total & 2.990 & 2.988 & 3.084 & 3.074 & 3.084 & 3.079 & 3.918 & 3.972 & 3.968 & 3.971 & 3.990 & 4.022 & 3.984 \\
\hline $\begin{array}{l}\mathrm{Fe}^{2+} \\
\mathrm{Fe}^{3+}\end{array}$ & 0.231 & 0.241 & $\begin{array}{l}0.566 \\
0.230\end{array}$ & 0.443 & 0.495 & 0.538 & 0.091 & 0.095 & 0.089 & 0.086 & 0.099 & 0.119 & 0.109 \\
\hline $\begin{array}{l}\mathrm{Fe}^{3+} \\
\mathrm{Ma} \#\end{array}$ & & 0877 & 0.230 & 0.211 & 0.224 & 0.225 & & & & & & & \\
\hline Mg\# & 0.883 & 0.817 & 0.411 & 0.532 & 0.482 & 0.442 & 0.929 & 0.902 & 0.906 & 0.913 & 0.909 & 0.900 & 0,893 \\
\hline $\mathrm{Cr} /(\mathrm{Cr}+\mathrm{Al})$ & & & 0.604 & 0.576 & 0.552 & 0.567 & & & & & & & \\
\hline \multicolumn{14}{|l|}{$\begin{array}{l}\mathrm{Ca} /(\mathrm{Ca}+\mathrm{Na}) \\
\mathrm{K} /(\mathrm{K}+\mathrm{Na})\end{array}$} \\
\hline $\mathrm{Fe}^{3+} /\left(\mathrm{Cr}+\mathrm{Al}+\mathrm{Fe}^{3+}\right)$ & & & 0.119 & 0.111 & 0.117 & 0.116 & & & & & & & \\
\hline $\mathrm{Al} /\left(\mathrm{Cr}+\mathrm{Al}+\mathrm{Fe}^{3+}\right)$ & & & 0.348 & 0.376 & 0.395 & 0.382 & & & & & & & \\
\hline $\mathrm{Cr} /\left(\mathrm{Cr}+\mathrm{Al}+\mathrm{Fe}^{3+}\right)$ & & & 0.532 & 0.512 & 0.487 & 0.501 & & & & & & & \\
\hline
\end{tabular}

\section{Chromian Spinel}

The $\mathrm{Cr} \#$ of chromian spinel is rather constant, from 0.4 to 0.6 and is, as a whole, negatively correlated with the $\mathrm{Mg \#} \mathrm{(Fig.} \mathrm{7).} \mathrm{Chromian}$

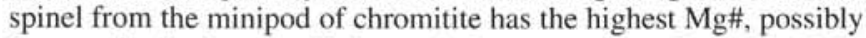
because it also has the highest spinel amount (e.g., Jackson, 1969; Arai, 1980). The $\mathrm{Fe}^{3+}$ content shows a clear positive correlation with $\mathrm{TiO}_{2}$ content (Fig. 8). The wehrlite spinel has lower values of $\mathrm{Mg} \#$ than the harzburgite spinel, although the $\mathrm{Cr} \#$ and $\mathrm{TiO}_{2}$ content are the same in both. The $\mathrm{TiO}_{2}$ content of chromian spinel is highly variable, from almost none to $3 \mathrm{wt} \%$, and has a weak positive correlation with the $\mathrm{Cr} \#$ for spinel from troctolite and olivine gabbro (Fig. 9). It is especially variable in olivine gabbro and very low, $<0.2 \mathrm{wt} \%$, but constant in harzburgite and wehrlite (Fig. 9). In dunite, the $\mathrm{TiO}_{2}$ content of spinel is relatively constant, from 0.5 to $1 \mathrm{wt} \%$ (Fig. 9). The chromian spinel with a sieve texture in the chromitite minipod has about $0.5 \mathrm{wt} \% \mathrm{TiO}_{2}$. The $\mathrm{TiO}_{2}$ content of chromian spinel in troctolite correlates well with the mode of occurrence; it is higher in the olivine-rich parts than in the plagioclase-rich parts both within and between samples (Fig. 9). This is concordant with the exclusive occurrence of rutile in a plagioclase-poor troctolite (PI. 1, Fig. 11). Chromian spinel in the dunite, closely associated with harzburgite, is relatively low in $\mathrm{TiO}_{2}$, at less than $1.2 \mathrm{wt} \%$ (Fig. 9). This is a remarkable contrast with the high $\mathrm{TiO}_{2}$ content (about $2 \mathrm{wt} \%$ ) of spinel in the plagioclase-poor rutile-bearing troctolite, which is the closest to dunite in mode of all troctolitic rocks (Fig. 9).

The $\mathrm{Cr} \#$ of spinel has a weak negative correlation with the Fo content of coexisting olivine (Fig. 4). Some pairs from olivine gabbro are off the general trend in the Cr\#-Fo plane (Fig. 4). It is note- worthy that the overall Cr\#-Fo trend for the Hess Deep rocks is almost coincident with that of mid-ocean-ridge basalt (MORB) (Fig. 10; Arai, 1994b).

\section{Mineral Inclusions in Chromian Spinel}

Both K- and Na-phlogopites in spinel from troctolite are highly Ti-rich, with 5 to 6 wt $\% \mathrm{TiO}_{2}$ (Table 1). The $\mathrm{TiO}_{2}$ content and the $\mathrm{Mg \#}$ of pargasite or pargasitic hornblende inclusions are 3 to $5 \mathrm{wt} \%$ and 0.87 to 0.90 , respectively, in troctolite and 2 to $3 w t \%$ and 0.92 to 0.93 , respectively, in the chromitite pod. Diopsidic clinopyroxene inclusions in troctolite spinel have a high $\mathrm{Mg} \#$, from 0.90 to $0.91,1.9$ to $2.1 \mathrm{wt} \% \mathrm{Al}_{2} \mathrm{O}_{3}$, and 1.0 to $1.3 \mathrm{wt} \% \mathrm{Cr}_{2} \mathrm{O}_{3}$. Those in chromitite spinel are more magnesian, with $\mathrm{Mg} \#$ values ranging from 0.91 to 0.93 . They are especially high in $\mathrm{Cr}_{2} \mathrm{O}_{3}$, from 1.6 to $2.3 \mathrm{wt} \%$, and relatively high in $\mathrm{Al}_{2} \mathrm{O}_{3}$, from 2.5 to $3.7 \mathrm{wt} \%$. The $\mathrm{TiO}_{2}$ content of the diopside inclusions is 0.54 to $1.2 \mathrm{wt} \%$ in troctolite and about $0.4 \mathrm{wt} \%$ in chromitite. Jadeite is close to an almost pure end member, with very low contents of kosmochlor and diopside molecules (Table 4). Orthopyroxene is relatively low in both $\mathrm{Al}_{2} \mathrm{O}_{3}$ and $\mathrm{Cr}_{2} \mathrm{O}_{3}$, mostly about $1 \mathrm{wt} \%$ and 1.2 to $1.5 \mathrm{wt} \%$, respectively. The $\mathrm{Mg \#}$ of orthopyroxene is comparable to that of diopside, from 0.92 to 0.93 .

\section{Plagioclase}

Plagioclase in troctolite is commonly highly calcic $\left(\mathrm{An}_{89-91}\right.$ in composition), especially in the plagioclase-rich part. It is noteworthy that plagioclases in inclusions in olivine range down to $\mathrm{An}_{79}$ in the same specimen. Plagioclase in olivine gabbro is also highly calcic, mostly 
Table 2 (continued).

147-895C-4R-2 (Piece 1B, 36-41 cm (continued)

147-895C-4R-2 (Piece 6B, 110-114 cm)

\begin{tabular}{|c|c|c|c|c|c|c|c|c|c|c|c|c|c|c|}
\hline Troctolite & $\operatorname{cp} \times 7$ & opx & rutile & kaer & ol & spl & $\mathrm{sp} 2$ & sp3 & sp4 & sp5 & sp6 & sp7 & $\begin{array}{l}\text { cpx } 1-1 \\
\text { (core) }\end{array}$ & $\begin{array}{c}\operatorname{cpx} 1-2 \\
\text { (rim) }\end{array}$ \\
\hline $\mathrm{SiO}_{2}$ & 52.87 & 55.69 & 0.21 & 44.33 & 41.36 & 0.40 & 0.32 & 0.49 & 0.65 & 0.49 & 0.44 & 0.39 & 51.81 & 51.45 \\
\hline $\mathrm{TiO}_{2}$ & 0.73 & 0.40 & 97.88 & 4.84 & 0.10 & 1.99 & 1.61 & 1.22 & 1.07 & 1.54 & 1.50 & 1.42 & 0.39 & 0.89 \\
\hline $\mathrm{Al}_{2} \mathrm{O}_{3}$ & 2.26 & 2.09 & 0.07 & 10.75 & 0.17 & 20.40 & 20.27 & 21.97 & 21.35 & 21.70 & 19.59 & 21.97 & 3.72 & 3.46 \\
\hline $\mathrm{Cr}_{2} \mathrm{O}_{3}$ & 0.84 & 0.70 & 0.96 & 1.35 & 0.05 & 37.87 & 40.31 & 39.74 & 39.80 & 37.22 & 40.16 & 38.74 & 1.48 & 1.45 \\
\hline $\mathrm{FeO}^{*}$ & 2.83 & 6.88 & 0.47 & 5.00 & 10.61 & 28.16 & 24.69 & 23.92 & 24.64 & 27.82 & 26.38 & 25.51 & 3.37 & 3.08 \\
\hline $\mathrm{MnO}$ & 0.09 & 0.13 & 0.07 & 0.05 & 0.12 & 0.13 & 0.11 & 0.13 & 0.14 & 0.04 & 0.17 & 0.22 & 0.15 & 0.22 \\
\hline $\mathrm{MgO}$ & 16.88 & 31.54 & 0.00 & 16.94 & 47.52 & 10.98 & 11.40 & 11.97 & 11.69 & 10.19 & 10.62 & 10.85 & 16.54 & 16.03 \\
\hline $\mathrm{CaO}$ & 23.40 & 2.41 & 0.04 & 10.89 & 0.14 & 0.20 & 0.23 & 0.26 & 0.24 & 0.14 & 0.15 & 0.16 & 21.84 & 22.52 \\
\hline $\mathrm{Na}_{2} \mathrm{O}$ & 0.00 & 0.00 & 0.00 & 2.54 & 0.00 & 0.00 & 0.00 & 0.01 & 0.00 & 0.00 & 0.01 & 0.00 & 0.00 & 0.00 \\
\hline $\mathrm{K}_{2} \mathrm{O}$ & 0.00 & 0.00 & 0.00 & 0.40 & 0.00 & 0.04 & 0.09 & 0.00 & 0.04 & 0.00 & 0.07 & 0.02 & 0.00 & 0.00 \\
\hline $\mathrm{P}_{2} \mathrm{O}_{5}$ & 0.20 & 0.29 & 0.20 & 0.21 & 0.13 & 0.05 & 0.04 & 0.00 & 0.11 & 0.08 & 0.00 & 0.00 & 0.00 & 0.31 \\
\hline $\mathrm{NiO}$ & 0.08 & 0.03 & 0.09 & 0.23 & 0.28 & 0.11 & 0.21 & 0.16 & 0.16 & 0.20 & 0.00 & 0.19 & 0.13 & 0.11 \\
\hline Total & 100.18 & 100.16 & 99.99 & 97.60 & 100.53 & 100.38 & 99.32 & 99.93 & 99.95 & 99.42 & .99 .09 & 99.47 & 99,43 & 99.52 \\
\hline $\mathrm{O}$ & & 6 & 2 & 23 & 4 & 4 & 4 & 4 & 4 & 4 & 4 & 4 & 6 & 6 \\
\hline Si & 1.922 & 1.935 & 0.002 & 6.329 & 1.010 & 0.013 & 0.010 & 0.015 & 0.020 & 0.015 & 0.014 & 0.012 & 1.899 & 1.886 \\
\hline $\mathrm{Ti}$ & 0.020 & 0.010 & 0.981 & 0.520 & 0.001 & 0.047 & 0.038 & 0.029 & 0.025 & 0.037 & 0.036 & 0.034 & 0.010 & 0.024 \\
\hline $\mathrm{Al}$ & 0.096 & 0.085 & 0.001 & 1.808 & 0.004 & 0.767 & 0.764 & 0.814 & 0.794 & 0.819 & 0.747 & 0.823 & 0.160 & 0.150 \\
\hline $\mathrm{Cr}$ & 0.024 & 0.019 & 0.010 & 0.153 & 0.001 & 0.955 & 1.019 & 0.987 & 0.993 & 0.942 & 1.026 & 0.974 & 0.043 & 0.042 \\
\hline $\mathrm{Fe}^{*}$ & 0.086 & 0.199 & 0.005 & 0.597 & 0.216 & 0.751 & 0.660 & 0.629 & 0.650 & $\begin{array}{l}0.942 \\
0.745\end{array}$ & 0.713 & 0.678 & 0.103 & 0.094 \\
\hline $\mathrm{Mn}$ & 0.002 & 0.003 & 0.000 & 0.006 & 0.002 & 0.003 & 0.003 & 0.003 & 0.003 & 0.001 & 0.004 & 0.005 & 0.004 & 0.006 \\
\hline $\mathrm{Mg}$ & 0.914 & 1.632 & 0.000 & 3.604 & 1.729 & 0.522 & 0.543 & 0.560 & 0.550 & 0.486 & 0.512 & 0.514 & 0.903 & 0.875 \\
\hline $\mathrm{Ca}$ & 0.911 & 0.090 & 0.000 & 1.665 & 0.003 & 0.007 & 0.007 & 0.008 & 0.008 & 0.004 & 0.005 & 0.005 & 0.857 & 0.884 \\
\hline $\mathrm{Na}$ & 0.000 & 0.000 & 0.000 & 0.704 & 0.000 & 0.000 & 0.000 & 0.001 & 0.000 & 0.000 & 0.001 & 0.000 & 0.000 & 0.000 \\
\hline $\mathrm{K}$ & 0.000 & 0.000 & 0.000 & 0.073 & 0.000 & 0.001 & 0.003 & 0.000 & 0.001 & 0.000 & 0.003 & 0.001 & 0.000 & 0.000 \\
\hline P & 0.006 & 0.008 & 0.002 & 0.026 & 0.002 & 0.001 & 0.001 & 0.000 & 0.003 & 0.002 & 0.000 & 0.000 & 0.000 & 0.009 \\
\hline $\mathrm{Ni}$ & 0.002 & 0.000 & 0.000 & 0.027 & 0.005 & 0.002 & 0.005 & 0.004 & 0.004 & 0.005 & 0.000 & 0.004 & 0.003 & 0.003 \\
\hline Total & 3.987 & 3.988 & 1.006 & 15.518 & 2.980 & 3.075 & 3.058 & 3.054 & 3.056 & 3.062 & 3.064 & 3.055 & 3.987 & 3.978 \\
\hline $\mathrm{Fe}^{2+}$ & 0.086 & 0.199 & & 0.597 & 0.216 & 0.445 & 0.427 & 0.417 & 0.429 & 0.487 & 0.463 & 0.460 & 0.103 & 0.094 \\
\hline $\mathrm{Fe}^{3+}$ & & & & & & 0.212 & 0.157 & 0.154 & 0.171 & 0.184 & 0.178 & 0.150 & & \\
\hline Mg\# & 0.914 & 0.891 & & 0.858 & 0.889 & 0.540 & 0.560 & 0.573 & 0.562 & 0.500 & 0.525 & 0.528 & 0.898 & 0.903 \\
\hline $\mathrm{Cr} /(\mathrm{Cr}+\mathrm{Al})$ & & & & & & 0.555 & 0.572 & 0.548 & 0.556 & 0.535 & 0.579 & 0.542 & & \\
\hline $\mathrm{Ca} /(\mathrm{Ca}+\mathrm{Na})$ & & & & & & & & & & & & & & \\
\hline $\mathrm{K} /(\mathrm{K}+\mathrm{Na})$ & & & & 0.094 & & & & & & & & & & \\
\hline $\mathrm{Fe}^{3+} /\left(\mathrm{Cr}+\mathrm{Al}+\mathrm{Fe}^{3+}\right)$ & & & & & & 0.110 & 0.081 & 0.079 & 0.087 & 0.095 & 0.091 & 0.077 & & \\
\hline $\mathrm{Al} /\left(\mathrm{Cr}+\mathrm{Al}+\mathrm{Fe}^{3+}\right)$ & & & & & & 0.397 & 0.394 & 0.416 & 0.406 & 0.421 & 0.383 & 0,423 & & \\
\hline $\mathrm{Cr} /\left(\mathrm{Cr}+\mathrm{Al}+\mathrm{Fe}^{3+}\right)$ & & & & & & 0.494 & 0.525 & 0.505 & 0.507 & 0.484 & 0.526 & 0.500 & & \\
\hline
\end{tabular}

about $\mathrm{An}_{90}$, but could range down to $\mathrm{An}_{86}$. These plagioclase crystals are as calcic as phenocrysts in some MORBs (e.g., Arai, 1981).

\section{Other Minerals}

Rutile in plagioclase-poor troctolite is almost pure $\mathrm{TiO}_{2}$ in composition, with about $1 \mathrm{wt} \% \mathrm{Cr}_{2} \mathrm{O}_{3}$. Kaersutite is associated with rutile in the plagioclase-poor troctolite, which is the only primary hydrous mineral that occurs outside of spinel. Kaersutite contains up to 4.9 wt $\% \mathrm{TiO}_{2}$.

\section{DISCUSSION}

\section{Comparison to Ophiolites}

The deep-seated rocks of the Pacific oceanic crust described in this article are similar to those of some ophiolite suites (e.g., Oman ophiolite), as previously suggested by Francheteau et al. (1990). The ultramafic rock association of the Hess Deep cores of Leg 147 indicates that they may represent the rocks around the petrologic Moho (Clague and Straley, 1977) of the Pacific lithosphere. Nicolas (1989) concluded that the Oman ophiolite was formed at a fast-spreading ridge system like the East Pacific Rise. Troctolitic rocks from Hess Deep are similar to troctolites or wehrlites from the Oman ophiolite (e.g., Benn et al., 1988). Benn et al. (1988) concluded that a crystal mush ("wehrlite magma"), rooted in the transition zone, intruded the higher-level plutonic rocks in the Oman ophiolite. As mentioned previously, the close association of dunite with feldspathic plutonic rocks (troctolites and gabbros) in the Hess Deep cores (Gillis, Mével,
Allan, et al., 1993) is similar to the contact relationships of indigenous gabbroic or pyroxenitic dikes with dunitic reaction rims observed in some ophiolites (e.g., Nicolas, 1989). The relative abundance of dunite suggests that the Hess Deep rocks are derived from a zone comparable to the transition zone of ophiolites (Nicolas and Prinzhofer, 1983). Cannat et al. (1990) also suggested that dredged samples (troctolite, plagioclase dunite, and harzburgite) from the Garret Transform Fault, which are similar to the Hess Deep samples, are derived from the transition zone of the Pacific lithosphere.

Harzburgite from Hess Deep is among the most depleted of the whole range of oceanic peridotites (e.g., Shibata and Thompson, 1986) in terms of the $\mathrm{Cr} \#$ of spinel and the spinel-olivine (Cr\#-Fo) compositional relationship (e.g., Dick et al., 1984; Michael and Bonatti, 1985; Dick, 1989; Bonatti et al., 1992; Arai, 1994a). It is typical of ophiolitic harzburgites (Arai, 1994a) and is actually similar to the basal harzburgite of the Oman ophiolite (Boudier and Coleman, 1981; Pallister and Hopson, 1981).

Primary hydrous mineral inclusions in chromian spinel from the Hess Deep troctolite and chromitite are especially important. Their presence in the transition zone of the Pacific Ocean indicates that a subducting slab is not necessary as the source of the volatiles in hydrous mineral inclusions in chromian spinel. The transition-zone rocks of ophiolites such as the Oman ophiolite are similar to the Hess Deep rocks, except that some podiform chromitites in Oman have chromian spinel with a higher $\mathrm{Cr} \#(0.7-0.8)$ than in any oceanic rocks ever documented. Note that the majority of the Oman chromitites have chromian spinel with a lower Cr\# (0.4 to 0.6) (e.g., Augé, 1987; Leblanc and Ceuleneer, 1992). 
Table 2 (continued).

\begin{tabular}{|c|c|c|c|c|c|c|c|c|c|c|c|}
\hline \multirow[b]{3}{*}{ Troctolite } & \multicolumn{11}{|c|}{$\begin{array}{l}\text { 147-895C-4R-2 (Piece 6B, 110-114 cm) } \\
\text { (continued) }\end{array}$} \\
\hline & \multirow[b]{2}{*}{$\begin{array}{l}\text { cpx2-1 } \\
\text { (rim) }\end{array}$} & \multirow[b]{2}{*}{$\begin{array}{l}\text { cpx } 2-2 \\
\text { (core) }\end{array}$} & \multirow[b]{2}{*}{$\begin{array}{l}\mathrm{cpx} 2-3 \\
\text { (rim) }\end{array}$} & \multirow[b]{2}{*}{$\operatorname{cpx} 3$} & \multirow[b]{2}{*}{ opx } & \multirow[b]{2}{*}{ plag } & \multicolumn{5}{|c|}{ Included by spinel } \\
\hline & & & & & & & $\mathrm{cpxl}$ & opx & amph & phl & cpx2 \\
\hline $\mathrm{SiO}_{2}$ & 52.35 & 52.12 & 52.12 & 51.58 & 55.22 & 46.14 & 51.53 & 57.18 & 44.17 & 40.86 & 52.70 \\
\hline $\mathrm{TiO}_{2}$ & 0.30 & 0.36 & 0.73 & 1.02 & 0.43 & 0.01 & 1.24 & 0.31 & 4.29 & $\begin{array}{r}4.00 \\
6.29\end{array}$ & 0.80 \\
\hline $\mathrm{Al}_{2} \mathrm{O}_{3}$ & 3.54 & 3.95 & 3.42 & 3.77 & 2.72 & 33.68 & 4.14 & 1.70 & 11.34 & 15.03 & 2.68 \\
\hline $\mathrm{Cr}_{2} \mathrm{O}_{3}$ & 1.38 & 1.41 & 1.29 & 1.41 & 0.64 & 0.05 & 1.30 & 0.69 & 2.41 & 2.13 & 1.47 \\
\hline $\mathrm{FeO}^{*}$ & 4.43 & 3.33 & 2.82 & 2.82 & 6.67 & 0.33 & 3.03 & 6.61 & 4.36 & 2.89 & 2.71 \\
\hline $\mathrm{MnO}$ & 0.08 & 0.08 & 0.14 & 0.11 & 0.16 & 0.00 & 0.03 & 0.09 & 0.05 & 0.02 & 0.10 \\
\hline $\mathrm{MgO}$ & 19.61 & 16.49 & 16.10 & 16.10 & 31.03 & 0.17 & 16.07 & 33.45 & 17.16 & 23.06 & 16.76 \\
\hline $\mathrm{CaO}$ & 17.32 & $\begin{array}{l}10.49 \\
21.83\end{array}$ & 22.58 & 22.37 & 2.73 & $\begin{array}{l}0.11 \\
17.63\end{array}$ & 21.83 & 0.84 & 11.86 & 0.17 & 22.80 \\
\hline $\mathrm{Na}_{2} \mathrm{O}$ & 0.14 & 0.00 & 0.00 & 0.14 & 0.04 & 1.00 & 0.35 & 0.14 & 2.60 & 5.75 & 0.00 \\
\hline $\mathrm{K}_{2} \mathrm{O}$ & 0.00 & 0.00 & 0.00 & 0.02 & 0.00 & 0.08 & 0.00 & 0.00 & 0.06 & 0.42 & 0.00 \\
\hline $\mathrm{P}_{2} \mathrm{O}_{5}$ & 0.07 & 0.22 & 0.00 & 0.00 & 0.00 & 0.00 & 0.26 & 0.01 & 0.08 & 0.00 & 0.16 \\
\hline $\mathrm{NiO}$ & 0.12 & 0.03 & 0.13 & 0.21 & 0.10 & 0.13 & 0.18 & 0.15 & 0.18 & 0.07 & 0.04 \\
\hline Total & 99.34 & 99.85 & 99.33 & 99.60 & 99.80 & 99.22 & 99.96 & 101.22 & 98.61 & 96.73 & 100.26 \\
\hline o & 6 & & & 6 & & 6 & & 6 & & 23 & 22 \\
\hline $\mathrm{Si}$ & 1.903 & 1.891 & 1.909 & 1.889 & 1.929 & 2.140 & 1.876 & 1.957 & 6.248 & 5.507 & 1.913 \\
\hline $\mathrm{Ti}$ & 0.008 & 0.010 & 0.020 & 0.028 & 0.011 & 0.000 & 0.034 & 0.008 & 0.456 & 0.638 & 0.021 \\
\hline $\mathrm{Al}$ & 0.151 & 0.170 & 0.147 & 0.163 & 0.112 & 1.840 & 0.177 & 0.068 & $\begin{array}{l}1.890 \\
1.890\end{array}$ & 2.387 & 0.115 \\
\hline $\mathrm{Cr}$ & 0.039 & 0.040 & 0.037 & 0.040 & 0.017 & 0.001 & 0.037 & 0.019 & 0.268 & 0.227 & 0.042 \\
\hline $\mathrm{Fe}^{*}$ & 0.134 & 0.102 & 0.087 & 0.086 & 0.195 & 0.013 & 0.092 & 0.189 & 0.514 & 0.326 & 0.082 \\
\hline $\mathrm{Mn}$ & 0.002 & 0.002 & 0.004 & 0.003 & 0.004 & 0.000 & 0.001 & 0.002 & 0.004 & 0.002 & 0.003 \\
\hline $\mathrm{Mg}$ & 1.062 & 0.900 & 0.879 & 0.878 & 1.615 & 0.011 & 0.872 & 1.705 & 3.615 & 4.633 & 0.906 \\
\hline $\mathrm{Ca}$ & 0.674 & 0.856 & 0.886 & 0.877 & 0.102 & 0.875 & 0.851 & 0.031 & 1.794 & 0.024 & 0.886 \\
\hline $\mathrm{Na}$ & 0.010 & 0.000 & $\begin{array}{l}0.0000 \\
0.000\end{array}$ & 0.010 & 0.003 & 0.090 & 0.025 & 0.009 & 0.713 & 1.500 & 0.000 \\
\hline $\mathrm{K}$ & 0.000 & 0.000 & 0.000 & 0.001 & 0.000 & 0.004 & 0.000 & 0.000 & 0.012 & 0.073 & 0.000 \\
\hline $\mathrm{P}$ & 0.002 & 0.007 & 0.000 & 0.000 & 0.000 & 0.000 & 0.008 & 0.000 & 0.008 & 0.000 & 0.005 \\
\hline $\mathrm{Ni}$ & 0.003 & 0.000 & 0.003 & 0.006 & 0.002 & 0.005 & 0.005 & 0.004 & 0.019 & 0.007 & 0.001 \\
\hline Total & 3.994 & 3.982 & 3.977 & 3.985 & 3.995 & 4.985 & 3.978 & 3.992 & 15.541 & 15.324 & 3.978 \\
\hline \multirow{7}{*}{$\begin{array}{l}\mathrm{Fe}^{2+} \\
\mathrm{Fe}^{3+} \\
\mathrm{Mg \#} \\
\mathrm{Cr} /(\mathrm{Cr}+\mathrm{Al}) \\
\mathrm{Ca} /(\mathrm{Ca}+\mathrm{Na}) \\
\mathrm{K} /(\mathrm{K}+\mathrm{Na}) \\
\mathrm{Fe}^{3+} /\left(\mathrm{Cr}+\mathrm{Al}+\mathrm{Fe}^{3+}\right) \\
\mathrm{Al} /\left(\mathrm{Cr}+\mathrm{Al}+\mathrm{Fe}^{3+}\right) \\
\mathrm{Cr} /\left(\mathrm{Cr}+\mathrm{Al}+\mathrm{Fe}^{3+}\right)\end{array}$} & 0.134 & 0.102 & 0.087 & 0.086 & 0.195 & & 0.092 & 0.189 & 0.514 & 0.326 & 0.082 \\
\hline & 0.888 & 0.898 & 0.910 & 0.911 & 0.892 & & 0.905 & 0.900 & 0.876 & 0.934 & 0.917 \\
\hline & & & & & & 0.907 & & & & & \\
\hline & & & & & & & & & 0.017 & 0.046 & \\
\hline & & & & & & & & & & & \\
\hline & & & & & & & & & & & \\
\hline & & & & & & & & & & & \\
\hline
\end{tabular}

\section{Mantle-Melt Interaction Products}

Mineral chemistry, as well as petrographic characteristics, may indicate that the ultramafic-mafic rock associations of Hess Deep, especially troctolitic rocks, are products of interaction between harzburgite and melt. Trends in mineral chemistry cannot be explained by simple fractional crystallization in the formation of dunite-troctolite-olivine gabbro (Figs. 5, 9). Crystal fractionation from a successively mixing melt does not produce the trends in mineral chemistry of the Hess Deep rocks. A combined process of the crystallization of melt and the dissolution of the pyroxene (orthopyroxene) component in harzburgite can explain the compositional variation of minerals in these rocks (Figs. 5, 9, 11). If a high-pressure melt ascends and then comes in contact with peridotite at a lower pressure, they should react (e.g., Quick, 1981; Fisk, 1986; Kelemen, 1990). Pyroxenes, especially orthopyroxene, should be attacked by the melt with the crystallization of olivine to release the latent heat to promote the interaction, because the high-pressure melt is undersaturated with pyroxene components and is usually oversaturated with olivine at low pressures (e.g., Kushiro, 1969). If the melt is stagnant enough and the interaction proceeds well, the melt could become enriched with some incompatible elements, such as $\mathrm{Ti}$, while the $\mathrm{Mg} \#$ would be only slightly variable because large amounts of magnesian olivine $\left(\mathrm{Fo}_{90-91}\right)$ would keep the $\mathrm{Mg} \#$ high to some extent (Kelemen, 1986) (Fig. 11). The Cr\# of the melt would also remain constant because the $\mathrm{Cr} \#$ would be counterbalanced by the crystallization of chromian spinel (i.e., $\mathrm{Cr}$ consumption) and dissolution of orthopyroxene, which is high in $\mathrm{Cr} \#$ (i.e., $\mathrm{Cr}$ supply) (Table 3).
Orthopyroxene in the orthopyroxene-bearing troctolite, which is also very poor in plagioclase, may be a relict of harzburgite orthopyroxene. The orthopyroxene in the troctolite locally shows a reaction relation with the melt to form clinopyroxene (Pl. 1, Fig. 10). Olivine in troctolite and olivine gabbro may also be partly a xenocryst phase (cf. Boudier, 1991), although chemically modified to some extent, and partly a precipitated phase. Olivine clots in these rocks may be chemically modified peridotite xenoliths. This interpretation is suggested by the fact that some of the olivine is kinked. Plagioclase and clinopyroxene may have crystallized from the melt. The amount of plagioclase and clinopyroxene, therefore, may parallel the amount of melt involved in the formation of the rocks.

The Ti enrichment of spinel and clinopyroxene in the plagioclase-poor troctolite (i.e., in the troctolite poorest in the melt component; Figs. 5, 9) may result from the involvement of the most evolved melt in the peripheral region of the interaction (Fig. 11). The amount of the melt involved is, however, the smallest in this part (Fig. 11). The enrichment in $\mathrm{Ti}$ and probably other incompatible elements may be more effective if the interaction process proceeds in a closed system. The chromian spinel and the clinopyroxene with low $\mathrm{TiO}_{2}$ contents in olivine gabbro (Figs. 5, 9) may have crystallized from the primitive melt (i.e., from the melt least affected by the interaction).

The dunite associated with harzburgite generally has a low-Ti mineralogy (Figs. 5, 9), in contrast with the plagioclase-poor troctolite, which could be transitional to dunite but has a high-Ti mineralogy. The low-Ti dunite could also be formed by melt-mantle interaction where the melt involved is less stagnant (Fig. 11). 
Table 2 (continued).

147-895C-4R-2 (Piece 8, 141-144 cm)

\begin{tabular}{|c|c|c|c|c|c|c|c|c|c|c|c|c|c|c|c|}
\hline \multirow[b]{2}{*}{ Troctolite } & \multirow[b]{2}{*}{ oll } & \multirow[b]{2}{*}{ spl } & \multirow[b]{2}{*}{$\mathrm{sp} 2$} & \multirow[b]{2}{*}{$\mathrm{sp} 3$} & \multirow[b]{2}{*}{ sp4 } & \multirow[b]{2}{*}{$\mathrm{cpxl}$} & \multirow[b]{2}{*}{$\operatorname{cpx} 2$} & \multirow[b]{2}{*}{ plag1 } & \multirow[b]{2}{*}{${ }^{*} \operatorname{cpx} 3$} & \multirow[b]{2}{*}{ "opx1 } & \multirow[b]{2}{*}{${ }^{*}$ opx 2} & \multicolumn{4}{|c|}{ Included by spinel } \\
\hline & & & & & & & & & & & & amph & K-phl & Na-phl & $\mathrm{cpx}$ \\
\hline $\mathrm{SiO}_{2}$ & 41.50 & 0.10 & 0.48 & 0.28 & 0.27 & 52.45 & 53.15 & 47.46 & 52.05 & 56.89 & 56.37 & 44.44 & 39.05 & 40.23 & 52.30 \\
\hline $\mathrm{TiO}_{2}$ & 0.07 & 1.86 & 0.90 & 1.16 & 1.40 & 0.62 & 0.39 & 0.06 & 0.83 & 0.35 & 0.30 & 3.46 & 5.77 & 6.01 & 0.59 \\
\hline $\mathrm{Al}_{2} \mathrm{O}_{3}$ & 0.42 & 20.05 & 20.94 & 20.57 & 19.92 & 3.54 & 3.59 & 33.10 & 3.42 & 2.39 & 2.44 & 11.70 & 15.33 & 15.32 & 2.96 \\
\hline $\mathrm{Cr}_{2} \mathrm{O}_{3}$ & 0.06 & 39.00 & 37.86 & 40.81 & 41.28 & 1.24 & 1.33 & 0.18 & 1.21 & 0.61 & 0.76 & 2.13 & 1.99 & 1.95 & 1.53 \\
\hline $\mathrm{FeO}^{*}$ & 10.07 & 25.49 & 29.70 & 25.49 & 25.31 & 3.32 & 4.10 & 0.36 & 2.95 & 6.85 & 6.83 & 3.90 & 2.49 & 2.55 & 2.78 \\
\hline $\mathrm{MnO}$ & 0.17 & 0.00 & 0.00 & 0.04 & 0.04 & 0.24 & 0.22 & 0.05 & 0.14 & 0.16 & 0.27 & 0.07 & 0.03 & 0.00 & 0.06 \\
\hline $\mathrm{MgO}$ & 47.82 & 11.07 & 9.08 & 11.43 & 11.26 & 16.54 & 18.52 & 0.00 & 15.88 & 31.69 & 31.77 & 17.03 & 22.24 & 22.68 & 16.61 \\
\hline $\mathrm{CaO}$ & 0.13 & 0.15 & 0.21 & 0.24 & 0.22 & 12.78 & 17.55 & 16.63 & 22.57 & 1.71 & 1.81 & 11.96 & 0.20 & 0.23 & 22.54 \\
\hline $\mathrm{Na}_{2} \mathrm{O}$ & 0.00 & 0.00 & 0.00 & 0.00 & 0.00 & 0.02 & 0.19 & 0.99 & 0.48 & 0.00 & 0.00 & 2.97 & 1.61 & 5.61 & 0.30 \\
\hline $\mathrm{K}_{2} \mathrm{O}$ & 0.03 & 0.00 & 0.01 & 0.06 & 0.04 & 0.00 & 0.00 & 0.07 & 0.00 & 0.00 & 0.00 & 0.09 & 6.66 & 0.43 & 0.03 \\
\hline $\mathrm{P}_{2} \mathrm{O}_{5}$ & 0.00 & 0.00 & 0.07 & 0.00 & 0.00 & 0.31 & 0.11 & 0.10 & 0.13 & 0.04 & 0.14 & 0.08 & 0.00 & 0.06 & 0.26 \\
\hline $\mathrm{NiO}$ & 0.31 & 0.12 & 0.23 & 0.11 & 0.20 & 0.09 & 0.13 & 0.18 & 0.11 & 0.05 & 0.12 & 0.05 & 0.14 & 0.22 & 0.23 \\
\hline Total & 100.58 & 97.89 & 99.48 & 100.19 & 99.94 & 100.19 & 99.34 & 99.18 & 99.83 & 100.80 & 100.86 & 97.93 & 95.51 & 95.29 & 100.19 \\
\hline O & 6 & 4 & 4 & 4 & 4 & 6 & 6 & 8 & 6 & 6 & 6 & 23 & 22 & 22 & 6 \\
\hline $\mathrm{Si}$ & 1.011 & 0.003 & 0.015 & 0.009 & 0.008 & 1.903 & 1.927 & 2.190 & 1.902 & 1.957 & 1.943 & 6.309 & 5.449 & 5.493 & 1.903 \\
\hline $\mathrm{Ti}$ & 0.001 & 0.045 & 0.022 & 0.027 & 0.033 & 0.016 & 0.010 & 0.002 & 0.022 & 0.009 & 0.007 & 0.368 & 0.605 & 0.616 & 0.016 \\
\hline Al & 0.012 & 0.769 & 0.801 & 0.770 & 0.750 & 0.151 & 0.153 & 1.800 & 0.147 & 0.097 & 0.099 & 1.957 & 2.519 & 2.464 & 0.127 \\
\hline $\mathrm{Cr}$ & 0.001 & 1.004 & 0.971 & 1.025 & 1.041 & 0.035 & 0.038 & 0.006 & 0.035 & 0.016 & 0.020 & 0.239 & 0.216 & 0.213 & 0.044 \\
\hline $\mathrm{Fe} *$ & 0.205 & 0.694 & 0.806 & 0.677 & 0.675 & 0.100 & 0.124 & 0.014 & 0.090 & 0.167 & 0.197 & 0.462 & 0.290 & 0.290 & 0.085 \\
\hline Mn & 0.003 & 0.000 & 0.000 & 0.001 & 0.001 & 0.007 & 0.007 & 0.002 & 0.004 & 0.004 & 0.008 & 0.007 & 0.007 & 0.000 & 0.002 \\
\hline $\mathrm{Mg}$ & 1.736 & 0.537 & 0.439 & 0.541 & 0.536 & 0.894 & 1.001 & 0.000 & 0.865 & 1.625 & 1.631 & 3.602 & 4.624 & 4.613 & 0.900 \\
\hline $\mathrm{Ca}$ & 0.003 & 0.005 & 0.007 & 0.008 & 0.007 & 0.846 & 0.682 & 0.821 & 0.883 & 0.063 & 0.067 & 1.817 & -0.029 & 0.033 & 0.878 \\
\hline $\mathrm{Na}$ & 0.000 & 0.000 & 0.000 & 0.000 & 0.000 & 0.002 & 0.013 & 0.089 & 0.034 & 0.000 & 0.000 & 0.819 & 0.436 & 1.485 & 0.020 \\
\hline $\mathrm{K}$ & 0.001 & 0.000 & 0.000 & 0.002 & 1.000 & 0.000 & 0.000 & 0.004 & 0.000 & 0.000 & 0.000 & 0.016 & 1.186 & 0.075 & 0.001 \\
\hline $\mathrm{P}$ & 0.000 & 0.000 & 0.002 & 0.000 & 0.000 & 0.009 & 0.003 & 0.004 & 0.004 & 0.001 & 0.004 & 0.009 & 0.000 & 0.004 & 0.008 \\
\hline $\mathrm{Ni}$ & 0.005 & 0.003 & 0.006 & 0.002 & 0.005 & 0.002 & 0.003 & 0.006 & 0.003 & 0.001 & 0.003 & 0.005 & 0.015 & 0.024 & 0.007 \\
\hline Total & 2.981 & 3.063 & 3.072 & 3.066 & 3.062 & 3.972 & 3.966 & 4.943 & 3.993 & 3.974 & 3.982 & 15.610 & 15.376 & 15.310 & 3.991 \\
\hline $\begin{array}{l}\mathrm{Fe}^{2+} \\
\mathrm{Fe}^{3+}\end{array}$ & 0.205 & $\begin{array}{l}0.434 \\
0.170\end{array}$ & $\begin{array}{l}0.552 \\
0.210\end{array}$ & $\begin{array}{l}0.445 \\
0.178\end{array}$ & $\begin{array}{l}0.443 \\
0.166\end{array}$ & 0.100 & 0.124 & & 0.090 & 0.167 & 0.197 & 0.462 & 0.290 & 0.290 & 0.085 \\
\hline $\mathrm{Mg} \#$ & 0.894 & 0.553 & 0.443 & 0.548 & 0.548 & 0.899 & 0.890 & & 0.906 & 0.907 & 0.892 & 0.886 & 0.941 & 0.941 & 0.914 \\
\hline $\mathrm{Cr} /(\mathrm{Cr}+\mathrm{Al})$ & & 0.566 & & & 0.581 & & & & & & & & & & \\
\hline $\mathrm{Ca} /(\mathrm{Ca}+\mathrm{Na})$ & & & & & & & & 0.902 & & & & & & & \\
\hline $\mathrm{K} /(\mathrm{K}+\mathrm{Na})$ & & & & & & & & & & & & 0.019 & 0.731 & 0.048 & \\
\hline $\mathrm{Fe}^{3+} /\left(\mathrm{Cr}+\mathrm{Al}+\mathrm{Fe}^{3+}\right)$ & & 0.087 & 0.106 & 0.090 & 0.085 & & & & & & & & & & \\
\hline $\mathrm{Al} /\left(\mathrm{Cr}+\mathrm{Al}+\mathrm{Fe}^{3+}\right)$ & & 0.396 & 0.404 & 0.390 & 0.383 & & & & & & & & & & \\
\hline $\mathrm{Cr} /\left(\mathrm{Cr}+\mathrm{Al}+\mathrm{Fe}^{3+}\right)$ & & 0.517 & 0.490 & 0.520 & 0.532 & & & & & & & & & & \\
\hline
\end{tabular}

\section{Concentration of Chromian Spinel and Implications for the Origin of Podiform Chromitites}

It is noteworthy that chromian spinel can be locally concentrated in the Hess Deep rocks. Furthermore, the petrographical characteristics (e.g., enrichment of mineral inclusions in spinel) are similar to those in the podiform chromitites in ophiolites (Talkington et al., 1986; Augé, 1987). The mode of occurrence of the spinel concentration in the Hess Deep rocks is essentially the same as that of podiform chromitites in ophiolites. As mentioned previously, the rodlike concentration of chromian spinel in dunite is a small-scale chromitite pod. The mode of concentration of chromian spinel in troctolite (Fig. 2 ) is consistent with a recent interpretation for origin of podiform chromitite (Arai and Yurimoto, 1992, 1994; Zhou et al., 1994) in which the mixing of magmas (a primitive melt and a Si- and Cr-rich melt formed by the dissolution of orthopyroxene from the harzburgite wall rock) plays an important role in the exclusive precipitation of chromian spinel to form chromitite, as Irvine (1977) originally proposed for the origin of layered chromitite. In troctolite from Hess Deep, chromian spinel is concentrated where the melt mixing could have occurred most effectively (Figs. 2, 12). The boundary region between the olivine-rich part and the plagioclase-rich part, where chromian spinel can be concentrated, may closely correspond to the original boundary area between the harzburgite wall rock and the melt pocket during interaction, where the mixing possibly occurs between the relatively $\mathrm{Si}$ - and $\mathrm{Cr}$-rich secondary melt supplied from the harzburgite wall and the newly supplied, more primitive melt (Fig. 12). Podiform chromitites could be formed in the oceanic upper mantle. However, the composition of chromian spinel in many podiform chromitites from some ophiolites, including Oman and Troodos, does not suggest an oceanic setting. The $\mathrm{Cr} \#$ of the chromitite spinel, most commonly 0.7 to 0.8 , is higher than that in any oceanic rocks ever documented, which are all lower than 0.7. Some aluminous chromitites (e.g., from the Tari-Misaka complex, southwestern Japan), which have chromian spinel with an intermediate $\mathrm{Cr} \#$ of about 0.5 (Arai, 1980; Arai and Yurimoto, 1994), could have been formed in the oceanic mantle.

The presence of high-Ti primary hydrous minerals in troctolite and in chromitite may mean that $\mathrm{H}_{2} \mathrm{O}, \mathrm{Na}, \mathrm{K}$, and $\mathrm{Ti}$ are concentrated by a process of interaction (cf. Kelemen, 1986). The combined process of zone refining and crystallization of olivine, which is essentially similar to the "partial zone refining" of Kushiro (1968), is possibly effective in concentrating these incompatible components during interaction. The selective presence of hydrous minerals as inclusions in chromian spinel in spinel-rich rocks implies that the highly evolved melt was involved in the formation and concentration of chromian spinel (Fig. 12). The highly evolved melt enriched in incompatible components might be one of the two end members of melt mixing (Fig. 12) to precipitate chromian spinel exclusively (Irvine, 1977; Arai and Yurimoto, 1994).

\section{Suggestions for the Evolution of MORB}

The origin of the primary MORB is controversial. Two end-member models have been proposed. O'Hara (1965) and Stolper (1980), among others, proposed that high-pressure melting of mantle peridotite produced picritic basalt, which was fractionated by olivine crystallization to form ordinary MORB. On the other hand, low-pressure 
Table 2 (continued).

\begin{tabular}{|c|c|c|c|c|c|c|c|c|c|c|c|}
\hline \multirow[b]{2}{*}{ Troctolite } & \multicolumn{6}{|c|}{ 147-895C-4R-3 (Piece $3,31-35 \mathrm{~cm}$ ) } & \multicolumn{5}{|c|}{ 147-895D-7R-1 (Piece 7, 41-43 cm) } \\
\hline & oll & spl & $\mathrm{sp} 2$ & $\mathrm{sp} 3$ & cpxl & plag 1 & oll & spl & $\mathrm{sp} 2$ & plag1 & $\begin{array}{l}\text { cpx (included } \\
\text { by spinel) }\end{array}$ \\
\hline $\mathrm{SiO}_{2}$ & 40.91 & 0.48 & 0.16 & 0.57 & 52.31 & 44.97 & 41.90 & 0.15 & 0.10 & 49.93 & 53.48 \\
\hline $\mathrm{TiO}_{2}$ & 0.07 & 1.01 & 1.25 & 1.83 & 0.57 & 0.05 & 0.01 & 1.29 & 0.84 & 0.12 & 0.59 \\
\hline $\mathrm{Al}_{2} \mathrm{O}_{3}$ & 0.24 & 21.46 & 20.66 & 19.07 & 3.50 & 32.32 & 0.38 & 21.48 & 22.41 & 30.42 & 2.89 \\
\hline $\mathrm{Cr}_{2} \mathrm{O}_{3}$ & 0.02 & 40.75 & 40.59 & 40.33 & 1.40 & 0.23 & 0.10 & 41.88 & 42.35 & 0.12 & 1.65 \\
\hline $\mathrm{FeO}^{*}$ & 10.13 & 23.85 & 25.31 & 26.86 & 3.17 & 0.21 & 10.36 & 21.90 & 21.09 & 0.39 & 3.05 \\
\hline $\mathrm{MnO}$ & 0.19 & 0.17 & 0.20 & 0.33 & 0.02 & 0.13 & 0.21 & 0.00 & 0.00 & 0.03 & 0.12 \\
\hline $\mathrm{MgO}$ & 48.37 & 11.69 & 11.59 & 10.61 & 16.77 & 0.10 & 46.88 & 11.96 & 12.28 & 0.22 & 15.57 \\
\hline $\mathrm{CaO}$ & 0.10 & 0.22 & 0.16 & 0.10 & 21.82 & 19.51 & 0.12 & 0.19 & 0.17 & 14.98 & 21.94 \\
\hline $\mathrm{Na}_{2} \mathrm{O}$ & 0.08 & 0.00 & 0.00 & 0.00 & 0.28 & 1.02 & 0.65 & 0.00 & 0.00 & 0.96 & 0.50 \\
\hline $\mathrm{K}_{2} \mathrm{O}$ & 0.00 & 0.08 & 0.08 & 0.00 & 0.02 & 0.36 & 0.02 & 0.04 & 0.01 & 2.71 & 0.03 \\
\hline $\mathrm{P}_{2} \mathrm{O}_{5}$ & 0.00 & 0.12 & 0.00 & 0.23 & 0.02 & 0.11 & 0.03 & 0.00 & 0.00 & 0.01 & 0.21 \\
\hline $\mathrm{NiO}$ & 0.31 & 0.07 & 0.00 & 0.17 & 0.06 & 0.10 & 0.26 & 0.10 & 0.15 & 0.09 & 0.17 \\
\hline Total & 100.42 & 99.90 & 100.00 & 100.10 & 99.94 & 99.11 & 100.98 & 99.04 & 99.46 & 100.05 & 100.2 \\
\hline $\mathrm{O}$ & 4 & 4 & 4 & 4 & 6 & 8 & 4 & 4 & 4 & 8 & 6 \\
\hline $\mathrm{Si}$ & 1.000 & 0.015 & 0.005 & 0.018 & 1.904 & 2.112 & 1.019 & 0.004 & 0.003 & 2.302 & 1.940 \\
\hline $\mathrm{Ti}$ & 0.001 & 0.024 & 0.030 & 0.044 & 0.015 & 0.001 & 0.000 & 0.030 & 0.020 & 0.004 & 0.016 \\
\hline $\mathrm{Al}$ & 0.007 & 0.797 & 0.774 & 0.720 & 0.150 & 1.788 & 0.011 & 0.801 & 0.828 & 1.652 & 0.123 \\
\hline $\mathrm{Cr}$ & 0.000 & 1.015 & 1.021 & 1.022 & 0.040 & 0.008 & 0.002 & 1.047 & 1.049 & 0.004 & 0.047 \\
\hline $\mathrm{Fe}^{*}$ & 0.207 & 0.628 & 0.673 & 0.720 & 0.096 & 0.008 & 0.210 & 0.579 & 0.552 & 0.015 & 0.092 \\
\hline $\mathrm{Mn}$ & 0.003 & 0.004 & 0.005 & 0.009 & 0.000 & 0.005 & 0.004 & 0.000 & 0.000 & 0.001 & 0.003 \\
\hline $\mathrm{Mg}$ & 1.762 & 0.549 & 0.549 & 0.507 & 0.909 & 0.007 & 1.699 & 0.564 & 0.573 & 0.015 & 0.841 \\
\hline $\mathrm{Ca}$ & 0.002 & 0.007 & 0.005 & 0.003 & 0.851 & 0.981 & 0.003 & 0.006 & 0.006 & 0.740 & 0.852 \\
\hline $\mathrm{Na}$ & 0.003 & 0.000 & 0.000 & 0.000 & 0.020 & 0.093 & 0.031 & 0.000 & 0.000 & 0.085 & 0.035 \\
\hline $\mathrm{K}$ & 0.000 & 0.003 & 0.003 & 0.000 & 0.001 & 0.022 & 0.000 & 0.001 & 0.000 & 0.159 & 0.001 \\
\hline$\ddot{\mathrm{P}}$ & 0.000 & 0.003 & 0.000 & 0.006 & 0.000 & 0.004 & 0.000 & 0.000 & 0.000 & 0.000 & 0.006 \\
\hline $\mathrm{Ni}$ & 0.006 & 0.001 & 0.000 & 0.004 & 0.001 & 0.004 & 0.005 & 0.002 & 0.003 & 0.003 & 0.004 \\
\hline Total & 2.996 & 3.051 & 3.068 & 3.056 & 3.993 & 5.038 & 2.988 & 3.040 & 3.038 & 4.986 & 3.966 \\
\hline $\mathrm{Fe}^{2+}$ & 0.207 & 0.431 & 0.437 & 0.453 & 0.096 & & 0.210 & 0.413 & 0.414 & & 0.092 \\
\hline $\mathrm{Fe}^{3+}$ & & 0.149 & 0.176 & 0.179 & & & & 0.106 & 0.098 & & \\
\hline $\mathrm{Mg} \#$ & 0.895 & 0.560 & 0.557 & 0.528 & 0.904 & & 0.890 & 0.577 & 0.580 & & 0.901 \\
\hline $\mathrm{Cr} /(\mathrm{Cr}+\mathrm{Al})$ & & 0.560 & 0.569 & 0.587 & & & & 0.567 & 0.559 & & \\
\hline $\mathrm{Ca} /(\mathrm{Ca}+\mathrm{Na})$ & & & & & & 0.913 & & & & 0.897 & \\
\hline $\mathrm{K} /(\mathrm{K}+\mathrm{Na})$ & & & & & & & & & & & \\
\hline $\mathrm{Fe}^{3+} /\left(\mathrm{Cr}+\mathrm{Al}+\mathrm{Fe}^{3+}\right)$ & & 0.076 & 0.089 & 0.093 & & & & 0.054 & 0.049 & & \\
\hline $\mathrm{Al} /\left(\mathrm{Cr}+\mathrm{Al}+\mathrm{Fe}^{3+}\right)$ & & 0.406 & 0.393 & 0.375 & & & & 0.410 & 0.419 & & \\
\hline $\mathrm{Cr} /\left(\mathrm{Cr}+\mathrm{Al}+\mathrm{Fe}^{3+}\right)$ & & 0.518 & 0.518 & 0.532 & & & & 0.536 & 0.531 & & \\
\hline
\end{tabular}

(about $0.1 \mathrm{GPa}$ ) formation of primary MORB by direct partial melting of mantle peridotite was proposed by Kushiro and Thompson (1972), Fujii and Bougault (1983), and Fujii and Scarfe (1985), among others. More recently, polybaric and incremental melting of mantle peridotite was proposed by McKenzie and Bickle (1988), Johnson et al. (1990), and Kinzler and Grove (1992a, 1992b). Highly refractory MORB can be preserved only as melt inclusions in early precipitating olivine (e.g., Sobolev and Shimizu, 1993). The possible modification of primitive MORB by mantle-melt interaction is suggested here.

The proposed "interaction trend" for the Cr\# of spinel and the Fo content of coexisting olivine in the Hess Deep rocks is almost coincident to that in the MORB (Fig. 10; Arai, 1994b). This suggests that the apparent "fractionation trend" observed in the primitive MORB may be, at least partly, the result of low-pressure interaction between the high-pressure MORB and harzburgite. The interaction discussed in this article is not wholly responsible for the evolution of MORB because the Ti content of chromian spinel in the Hess Deep troctolite (up to $3 \mathrm{wt} \%$ ) is much higher than in ordinary Atlantic MORB (usually less than 1 wt\%) (e.g., Dick and Bullen, 1984; Arai, 1992). This possibly indicates that not N-type MORB but E- or T-type MORB was involved in the formation of the Hess Deep rocks. But we can equally well assume that the Ti enrichment was performed in a closed-system interaction in which olivine formation was predominant from $\mathrm{N}$-type MORB. Furthermore, Pacific MORB has higher Ti contents than Atlantic MORB (e.g., Flower, 1980), and it is possible that the former has initially Ti-rich spinel. The dunite associated with harzburgite has chromian spinel with less than $1 \mathrm{wt} \% \mathrm{TiO}_{2}$ and could be in equilibrium with some primitive N-type MORB (e.g., Arai, 1992, 1994b).

\section{SUMMARY AND CONCLUSIONS}

1. Dunite was found commonly within harzburgite in some core sections from Site 895 of Leg 147. The close association of the dunite with feldspathic plutonic rocks, gabbros, and troctolites indicates that the dunite is a halo of interaction or depletion around injected melt.

2. The gabbro-troctolite-dunite complex is the interaction product between the injected melt and harzburgite wall rock in the shallowest mantle. The harzburgite changes gradually into gabbro via dunite, troctolite, and olivine gabbro. Petrographic and mineral chemical variations result from a gradation in the degree of interaction and in the proportion of melt and harzburgite.

3. The peridotites and associated mafic plutonic rocks from Hess Deep are basically similar to those of the transition zone of some typical ophiolites (e.g., Oman ophiolite). They were derived from the transitional zone of the Pacific lithosphere. The Hess Deep harzburgite, which has chromian spinel with an intermediate $\mathrm{Cr} \#$ of about 0.5 to 0.6 , belongs to the most refractory group of the oceanic peridotites and is equivalent to average ophiolitic harzburgite. The podiform chromitites of most ophiolites have, however, high-Cr\# $(0.7-0.8)$ chromian spinel, whereas all oceanic rocks ever documented have chromian spinel with lower $\mathrm{Cr} \#(<0.7)$.

4. Podiform chromitites can be formed in the oceanic mantle conditions. A chromitite pod was discovered and chromian spinel concentrations are common in dunite and troctolite. Chromian spinels in those rocks typically have mineral inclusions of phlogopites, pargasite, and pyroxene, as in the case of podiform chromitites from ophiolites. The mechanism of the spinel concentration can be interpreted as essentially the same as in the podiform chromitites. 
5. Low-pressure interaction with the harzburgite wall may contribute to the evolution of the primitive MORB erupted on the ocean floor. The interaction is expected to be more prevalent beneath fastspreading ridges than beneath slow-spreading ridges.

\section{ACKNOWLEDGMENTS}

S.A. is greatly indebted to E. Kikawa for his encouragement and discussion during and after the cruise of Leg 147. A. Taira greatly assisted S.A. in participating on the ODP cruise. S.A. wishes to express his deep thanks to K. Gillis, C. Mével, J. Allan, the other shipboard scientists, all marine technicians and specialists, and the captain and crew of JOIDES Resolution for their collaboration, kindness, and friendship during Leg 147. Discussions with H. Dick, J. Allan, H. Prichard, C. Lécuyer, and F. Boudier were especially helpful for us. Comments and suggestions by P. Kelemen, J. Casey, and P. Meyer were of great help in improving the manuscript. We are grateful to $\mathrm{E}$. Isobe for his collaboration with us in the laboratory. $\mathrm{H}$. Okubo and $\mathrm{N}$. Abe kindly helped us to prepare some of the figures.

\section{REFERENCES}

Arai, S., 1978. Chromian spinel lamellae in olivine from the Iwanai-dake peridotite mass, Hokkaido, Japan. Earth Planet. Sci. Lett., 39:267-273. , 1980. Dunite-harzburgite-chromitite complexes as refractory residue in the Sangun-Yamaguchi zone, western Japan. J. Petrol., 21:141165 .

- 1981. Petrology of basalts from Site 487, Deep Sea Drilling Project Leg 66, Middle America Trench area off Mexico. In Watkins, J.S., Moore, J.C., et al., Init. Repts. DSDP, 66: Washington (U.S. Govt. Printing Office), 711-722.

, 1992. Chemistry of chromian spinels in volcanic rocks as a potential guide to magma chemistry. Mineral. Mag.. 56:173-184.

, 1994a. Characterization of spinel peridotites by olivine-spinel compositional relationships: review and interpretation. Chem. Geol., 113:191-204.

1994b. Compositional variation of olivine-chromian spinel in $\mathrm{Mg}$-rich magmas as a guide to their residual spinel peridotites. J. Volcanol. Geotherm. Res., 59:279-293.

Arai, S., Inoue, T., and Oyama, T., 1988. Igneous petrology of the OchiaiHokubo ultramafic complex, the Sangun zone, western Japan: a preliminary report. Chishitsugaku Zasshi [J. Geol. Soc. Jpn.], 94:91-102. (in Japanese with English abstract)

Arai, S., and Yurimoto, H., 1992. Origin of podiform chromitites from Southwest Japan as a melt-mantle interaction. 29th Int. Geol. Congr., Kyoto, Abstr., 1:176.

1994. Podiform chromitites from the Tari-Misaka ultramafic complex, southwestern Japan, as mantle-melt interaction products. Econ. Geol., 89:1279-1288.

Atkins, F.B., 1969. Pyroxenes of the Bushveld intrusion. J. Petrol., 10:222249.

Augé, T., 1987. Chromite deposits in the northern Oman ophiolite: mineralogical constraints. Miner. Deposita, 22:1-10.

Benn, K., Nicolas, A., and Reuber, I., 1988. Mantle-crust transition zone and origin of wehrlitic magmas: evidence from the Oman ophiolite. Tectonophysics, 151:75-85.

Bonatti. E., and Honnorez, J., 1976. Sections of the earth's crust in equatorial Atlantic. J. Geophys. Res., 81:4104-4116.

Bonatti, E., Peyve, A., Kepezhinskas, P., Kurentsova, N., Seyler, M., Skolotnev, S., and Udintsev, G., 1992. Upper mantle heterogeneity below the Mid-Atlantic Ridge, $0^{\circ}-15^{\circ}$ N. J. Geophys. Res., 97:4461-4476.

Boudier, F., 1991. Olivine xenocrysts in picritic magmas: an experimental and microstructural study. Contrib. Mineral. Petrol., 109:114-123.

Boudier, F., and Coleman, R.G., 1981. Cross section through the peridotite in the Samail ophiolite, southeastern Oman Mountains. J. Geophys. Res. 86:2573-2592.

Boudier, F., Le Sueur, E., and Nicolas, A., 1989. Structure of an atypical ophiolite: the Trinity Complex, eastern Klamath Mountains, California. Geol. Soc. Am. Bull., 101:820-833.
Cannat, M., 1993. Emplacement of mantle rocks in the seafloor at mid-ocean ridges. J. Geophys. Res., 98:4163-4173.

Cannat, M., Bideau, D., and Hebert, R., 1990. Plastic deformation and magmatic impregnation in serpentinized ultramafic rocks from the Garret transform fault (East Pacific Rise). Earth Planet. Sci. Lett., 101:216-232.

Cassard, D., Nicolas, A., Rabinovitch, M., Moutte, J., Leblanc, M., and Prinzhofer, A., 1981. Structural classification of chromite pods in southern New Caledonia. Econ. Geol., 76:805-831.

Clague, D.A., and Straley, P.F., 1977. Petrologic nature of the oceanic Moho. Geology, 5:133-136.

Dick, H.J.B., 1989. Abyssal peridotites, very slow spreading ridges and ocean ridge magmatism. In Saunders, A.D., and Norry, M.J. (Eds.), Magmatism in the Ocean Basins. Geol. Soc. Spec. Publ. London, 42:71-105.

Dick, H.J.B., and Bullen, T., 1984. Chromian spinel as a petrogenetic indicator in abyssal and alpine-type peridotites and spatially associated lavas. Contrib. Mineral. Petrol., 86:54-76.

Dick, H.J.B., Fisher, R.L., and Bryan, W.B., 1984. Mineralogic variability of the uppermost mantle along mid-ocean ridges. Earth Planet. Sci. Lett., 69:88-106.

Fisk, M.R., 1986. Basalt magma interaction with harzburgite and the formation of high-magnesian andesite. Geophys. Res. Lett., 13:467-470.

Flower, M.F.J., 1980. Accumulation of calcic plagioclase in ocean-ridge tholeiite: an indication of spreading rate? Nature, 287:530-532.

, 1981. Thermal and kinematic control on ocean-ridge magma fractionation: contrasts between Atlantic and Pacific spreading axes. J. Geol. Soc. London, 138:695-712.

Francheteau, J., Armijo, R., Cheminée, J.L., Hekinian, R., Lonsdale, P., and Blum, N., 1990. 1 Ma East Pacific Rise oceanic crust and uppermost mantle exposed by rifting in Hess Deep (equatorial Pacific Ocean). Earth Planet. Sci. Lett., 101:281-295.

, 1992. Dyke complex of the East Pacific Rise exposed in the walls of Hess Deep and the structure of the upper oceanic crust. Earth Planet. Sci. Lett., 111:109-121.

Fujii, T., and Bougault, H., 1983. Melting relations of a magnesian abyssal tholeiite and the origin of MORBs. Earth Planet. Sci. Lett., 62:283-295.

Fujii, T., and Scarfe, C.M., 1985. Composition of liquids coexisting with spinel therzolite at $10 \mathrm{kbar}$ and the genesis of MORBs. Contrib. Mineral. Petrol., 90:18-28.

Gillis, K., Mével, C., Allan, J., et al., 1993. Proc. ODP, Init. Repts., 147: College Station, TX (Ocean Drilling Program).

Girardeau, J., and Francheteau, J., 1993. Plagioclase-wehrlites and peridotites on the East Pacific Rise (Hess Deep) and the Mid-Atlantic Ridge (DSDP Site 334): evidence for magma percolation in the oceanic upper mantle. Earth Planet. Sci. Lett., 115:137-149.

Hebert, R., Bideau, D., and Hekinian, R., 1983. Ultramafic and mafic rocks from the Garret transform fault near $13^{\circ} 30^{\prime} \mathrm{S}$ on the East Pacific Rise: igneous petrology. Earth Planet. Sci. Lett., 65:107-125.

Hekinian, R., Bideau, D., Francheteau, J., Cheminee, J.L., Armijo, R., Lonsdale, P., and Blum, N., 1993. Petrology of the East Pacific Rise crust and upper mantle exposed in the Hess Deep (eastern equatorial Pacific). $J$. Geophys. Res., 98:8069-8094.

Irvine, T.N., 1975. Crystallization sequences in the Muskox Intrusion and other layered intrusions, II: origin of chromitite layers and similar deposits of other magmatic ores. Geochim. Cosmochim. Acta, 39:991-1020.

- 1977. Origin of chromitite layers in the Muskox Intrusion and other stratiform intrusions: a new interpretation. Geology, 5:273-277.

Jackson, E.D., 1969. Chemical variation in co-existing chromite and olivine in chromite zones of the Stillwater complex. In Wilson, H.D.B. (Ed.), Magmatic Ore Deposits. Econ. Geol. Monogr., 6:41-71.

Johan, Z., 1986. Chromite deposits in the Massif du Sud ophiolite, New Caledonia: genetic consideration. In Petrascheck, W., et al. (Eds.), Chromites: Athens (Theophrastus), 311-339.

Johan, Z., Dunlop, H., Le Bel, L., Robert, J.L., and Volfinger, M., 1983. Origin of chromite deposits in ophiolitic complexes: evidence for a volatileand sodium-rich reducing fluid phase. Fortschr. Mineral., 61:105-107.

Johnson, K.T.M., Dick, H.J.B., and Shimizu, N., 1990. Melting in the oceanic upper mantle: an ion microprobe study of diopsides in abyssal peridotites. J. Geophys. Res., 95:2661-2678.

Kelemen, P.B., 1986. Assimilation of ultramafic rocks in subduction-related magmatic arcs. J. Geol., 94:829-843.

1990. Reaction between ultramafic rock and fractionating basaltic magma, I. Phase relations, the origin of calc-alkaline magma series, and the formation of discordant dunite. J. Petrol., 31:51-98. 
Kinzler, R.J., and Grove, T.L., 1992a. Primary magmas of mid-ocean ridge basalts, 1: experiments and methods. J. Geophys. Res., 97:6885-6906.

1992b. Primary magmas of mid-ocean ridge basalts, 2: applications. J. Geophys. Res., 97:6907-6926.

Kushiro, I., 1968. Compositions of magmas formed by partial zone melting in the earth's upper mantle. J. Geophys. Res., 73:619-634.

, 1969. The system forsterite-diopside-silica with and without water at high pressures. Am. J. Sci., The Schairer Vol., 267-A:269-294.

Kushiro, I., and Thompson, R.N., 1972. Origin of some abyssal tholeiites from the Mid-Atlantic Ridge. Yearbook-Carnegie Inst. Washington, 71:403-406.

Lago, B.L., Rabinowicz, M., and Nicolas, A., 1982. Podiform chromite ore bodies: a genetic model. J. Petrol., 23:103-125.

Leblanc, M., and Ceuleneer, G., 1992. Chromite crystallization in a muticellular magma flow: evidence from a chromitite dike in the Oman ophiolite. Lithos, 27:231-257.

McElduff, B., and Stumpfl, E.F., 1991. The chromite deposits of the Troodos Complex, Cyprus - evidence for the role of a fluid phase accompanying chromite formation. Mineral. Deposita, 26:307-318.

McKenzie, D., and Bickle, M.J., 1988. The volume and composition of melt generated by extension of the lithosphere. Jour. Petrol., 29:625-679.

Michael, P.J., and Bonatti, E., 1985. Peridotite composition from the North Atlantic: regional and tectonic variations and implications for partial melting. Earth Planet. Sci. Lett., 73:91-104.

Nicolas, A., 1989. Structure of Ophiolites and Dynamics of the Oceanic Lithosphere: Dordrecht (Kluwer).

Nicolas, A., and Prinzhofer, A., 1983. Cumulative or residual origin for the transition zone in ophiolites: structural evidence. J. Petrol., 24:188-206.

Pallister, J.S., and Hopson, C.A., 1981. Samail ophiolite plutonic suite: field relations, phase variation, cryptic variation and layering, and a model of a spreading ridge magma chamber. J. Geophys. Res., 86:2593-2644.

Quick, J.E., 1981. The origin and significance of large, tabular dunite bodies in the Trinity peridotite, northern California. Contrib. Mineral. Petrol.,78:413-422.
Shibata, T., and Thompson, G., 1986. Peridotites from the Mid-Atlantic Ridge at $43^{\circ} \mathrm{N}$ and their petrogenetic relation to abyssal tholeiites. Contrib. Mineral. Petrol., 93:144-159.

Sinton, J.M., and Detrick, R.S., 1992. Mid-ocean ridge magma chambers. $J$. Geophys. Res., 97:197-216.

Sobolev, A.V., and Shimizu, N., 1993. Ultra-depleted primary melt included in an olivine from the Mid-Atlantic Ridge. Nature, 363:151-154.

Stolper, E., 1980. A phase diagram for mid-ocean ridge basalts: preliminary results and implications for petrogenesis. Contrib. Mineral. Petrol., 74:13-27.

Talkington, R.W., Watkinson, D.H., Whittaker, P.J., and Jones, P.C., 1984. Platinum group minerals and other solid inclusions in chromites of ophiolitic complexes: occurrence and petrological significance. TMPM, Tschermaks Mineral. Petrogr. Mitt., 32:285-300.

, 1986. Platinum group element-bearing minerals and other solid inclusions in chromite of mafic and ultramafic complexes: chemical compositions and comparisons. In Carter, B., et al. (Eds.), Metammogeny of Basic and Ultrabasic Rocks (Regional Presentations): Athens (Theophrastus), 223-249.

Thayer, T.P., 1964. Principal features and origin of podiform chromite deposits and some observations on the Guleman-Soridag district, Turkey. Econ. Geol., 59:1497-1524.

Zhou, M.-F., Robinson, P.T., and Bai, W.-J., 1994. Formation of podiform chromitites by melt/rock interaction in the upper mantle. Miner. Deposita, 29:98-101.

\section{Date of initial receipt: 2 August 1994 \\ Date of acceptance: 5 January 1995 \\ Ms 147SR-008}

Table 3. Selected microprobe analyses of minerals in wehrlite, dunite, and harzburgite from Site 895, Hess Deep.

\begin{tabular}{|c|c|c|c|c|c|c|c|c|c|c|c|c|c|c|}
\hline & \multirow{2}{*}{\multicolumn{3}{|c|}{$\begin{array}{l}\text { Wehrlite } \\
7-895 C-3 R-1 \\
22,130-133 \mathrm{~cm})\end{array}$}} & \multicolumn{4}{|c|}{ Dunite } & \multirow{2}{*}{\multicolumn{4}{|c|}{$\begin{array}{c}147-895 \mathrm{D}-4 \mathrm{R}-2 \\
\text { (Piece } 7,45-49 \mathrm{~cm} \text { ) }\end{array}$}} & \multirow{2}{*}{\multicolumn{3}{|c|}{$\begin{array}{c}\text { 147-895E-6R-2 } \\
\text { (Piece 5E, 77-80 cm) }\end{array}$}} \\
\hline & & & & & $\begin{array}{r}\text { 147-895 } \\
\text { (Piece 4, }\end{array}$ & $\begin{array}{l}-4 \mathrm{R}-3 \\
-43 \mathrm{~cm})\end{array}$ & & & & & & & & \\
\hline & oll & spl & cpxI & oll & spl & $\mathrm{sp} 2$ & cpxl & oll & spl & $\mathrm{sp} 2$ & $\mathrm{sp} 3$ & oll & spl & $\mathrm{sp} 2$ \\
\hline $\begin{array}{l}\mathrm{SiO}_{2} \\
\mathrm{TiO}_{2} \\
\mathrm{Al}_{2} \mathrm{O}_{3} \\
\mathrm{Cr}_{2} \mathrm{O}_{3} \\
\mathrm{FeO}^{*} \\
\mathrm{MnO} \\
\mathrm{MgO} \\
\mathrm{CaO} \\
\mathrm{Na}_{2} \mathrm{O} \\
\mathrm{K}_{2} \mathrm{O} \\
\mathrm{P}_{2} \mathrm{O}_{5} \\
\mathrm{NiO} \\
\text { Total }\end{array}$ & $\begin{array}{c}41.31 \\
0.11 \\
0.23 \\
0.11 \\
9.3 \\
0.21 \\
47.94 \\
0.14 \\
0.25 \\
0.03 \\
0 \\
0.44 \\
100.14\end{array}$ & $\begin{array}{c}0.26 \\
0.11 \\
24.51 \\
40.55 \\
21.67 \\
0 \\
11.14 \\
0.13 \\
0 \\
0.04 \\
0.03 \\
0.22 \\
98.7\end{array}$ & $\begin{array}{c}52.13 \\
0.06 \\
3 \\
1.16 \\
2.8 \\
0.12 \\
17.91 \\
21.77 \\
0 \\
0.01 \\
0.05 \\
0.16 \\
99.2\end{array}$ & $\begin{array}{c}40.72 \\
0.05 \\
0.17 \\
0.08 \\
9.72 \\
0.14 \\
48.61 \\
0.06 \\
0 \\
0.03 \\
0.18 \\
0.3 \\
100.06\end{array}$ & $\begin{array}{r}0.57 \\
0.82 \\
22.18 \\
39.41 \\
26.59 \\
0.48 \\
9.43 \\
0.06 \\
0 \\
0 \\
0.07 \\
0.2 \\
99.81\end{array}$ & $\begin{array}{c}0.43 \\
1.02 \\
19.97 \\
41 \\
27.49 \\
0.75 \\
9.04 \\
0.17 \\
0 \\
0 \\
0 \\
0.09 \\
99.96\end{array}$ & $\begin{array}{c}52.17 \\
0.37 \\
3.17 \\
1.6 \\
3.67 \\
0.17 \\
18.98 \\
19.28 \\
0 \\
0 \\
0.25 \\
0.18 \\
99.88\end{array}$ & $\begin{array}{c}41.7 \\
0.07 \\
0.01 \\
0.06 \\
9.22 \\
0.2 \\
49.69 \\
0.09 \\
0 \\
0.01 \\
0.2 \\
0.54 \\
101.83\end{array}$ & $\begin{array}{c}0.48 \\
0.01 \\
25.23 \\
43.76 \\
18.13 \\
0.56 \\
12.43 \\
0.17 \\
0 \\
0.02 \\
0 \\
0.1 \\
100.94\end{array}$ & $\begin{array}{c}0.51 \\
0.17 \\
17.54 \\
37.51 \\
34.28 \\
0.39 \\
9.44 \\
0.15 \\
0 \\
0.04 \\
0.17 \\
0.25 \\
100.5\end{array}$ & $\begin{array}{r}0.36 \\
0.24 \\
25.03 \\
43.87 \\
17.89 \\
0.42 \\
13.35 \\
0.15 \\
0 \\
0 \\
0.05 \\
0.16 \\
101.57\end{array}$ & $\begin{array}{r}41.13 \\
0.07 \\
0.39 \\
0.03 \\
9.02 \\
0.17 \\
48.95 \\
0.25 \\
0.13 \\
0.03 \\
0 \\
0.47 \\
100.64\end{array}$ & $\begin{array}{c}0.23 \\
0.9 \\
23.76 \\
41.95 \\
19.18 \\
0 \\
13.58 \\
0.12 \\
0 \\
0.08 \\
0 \\
0.25 \\
100.05\end{array}$ & $\begin{array}{c}0.15 \\
0.52 \\
26.43 \\
40.72 \\
17.25 \\
0 \\
15.25 \\
0.21 \\
0 \\
0 \\
0.12 \\
0.1 \\
100.75\end{array}$ \\
\hline $\begin{array}{l}\mathrm{O} \\
\mathrm{Si} \\
\mathrm{Ti} \\
\mathrm{Al} \\
\mathrm{Cr} \\
\mathrm{Fe} \\
\mathrm{Mn} \\
\mathrm{Mg} \\
\mathrm{Ca} \\
\mathrm{Na} \\
\mathrm{K} \\
\mathrm{P} \\
\mathrm{Ni} \\
\text { Total }\end{array}$ & $\begin{array}{l}4 \\
1.01 \\
0.002 \\
0.006 \\
0.002 \\
0.19 \\
0.004 \\
1.747 \\
0.003 \\
0.012 \\
0 \\
0 \\
0.008 \\
2.989\end{array}$ & $\begin{array}{l}4 \\
0.008 \\
0.002 \\
0.908 \\
1.007 \\
0.569 \\
0 \\
0.521 \\
0.004 \\
0 \\
0.001 \\
0.001 \\
0.005 \\
3.03\end{array}$ & $\begin{array}{l}6 \\
1.91 \\
0.001 \\
0.129 \\
0.033 \\
0.085 \\
0.003 \\
0.977 \\
0.854 \\
0 \\
0 \\
0.001 \\
0.004 \\
4.004\end{array}$ & $\begin{array}{l}4 \\
0.997 \\
0 \\
0.005 \\
0.001 \\
0.199 \\
0.003 \\
1.773 \\
0.001 \\
0 \\
0.001 \\
0.003 \\
0.005 \\
2.993\end{array}$ & $\begin{array}{l}4 \\
0.018 \\
0.019 \\
0.833 \\
0.993 \\
0.709 \\
0.013 \\
0.448 \\
0.002 \\
0 \\
0 \\
0.001 \\
0.005 \\
3.045\end{array}$ & $\begin{array}{l}4 \\
0.014 \\
0.024 \\
0.761 \\
1.047 \\
0.743 \\
0.02 \\
0.435 \\
0.005 \\
0 \\
0 \\
0 \\
0.002 \\
3.056\end{array}$ & $\begin{array}{l}6 \\
1.894 \\
0.01 \\
0.135 \\
0.046 \\
0.111 \\
0.005 \\
1.026 \\
0.749 \\
0 \\
0 \\
0.007 \\
0.005 \\
3.992\end{array}$ & $\begin{array}{l}4 \\
1.001 \\
0.001 \\
0 \\
0.001 \\
0.185 \\
0.004 \\
1.778 \\
0.002 \\
0 \\
0 \\
0.004 \\
0.01 \\
2.99\end{array}$ & $\begin{array}{l}4 \\
0.014 \\
0 \\
0.901 \\
1.048 \\
0.459 \\
0.014 \\
0.561 \\
0.005 \\
0 \\
0 \\
0 \\
0.002 \\
3.01\end{array}$ & $\begin{array}{l}4 \\
0.017 \\
0.004 \\
0.685 \\
0.983 \\
0.95 \\
0.011 \\
0.466 \\
0.005 \\
0 \\
0.002 \\
0.004 \\
0.006 \\
3.137\end{array}$ & $\begin{array}{l}4 \\
0.01 \\
0.005 \\
0.887 \\
1.042 \\
0.45 \\
0.01 \\
0.598 \\
0.004 \\
0 \\
0 \\
0.001 \\
0.003 \\
3.016\end{array}$ & $\begin{array}{l}4 \\
0.999 \\
0.001 \\
0.011 \\
0 \\
0.183 \\
0.003 \\
1.772 \\
0.006 \\
0.006 \\
0.001 \\
0 \\
0.009 \\
2.996\end{array}$ & $\begin{array}{l}4 \\
0.006 \\
0.02 \\
0.86 \\
1.018 \\
0.492 \\
0 \\
0.622 \\
0.003 \\
0 \\
0.003 \\
0 \\
0.006 \\
2.996\end{array}$ & $\begin{array}{l}4 \\
0.004 \\
0.011 \\
0.931 \\
0.962 \\
0.431 \\
0 \\
0.679 \\
0.006 \\
0 \\
0 \\
0.003 \\
0.002 \\
3.032\end{array}$ \\
\hline $\begin{array}{l}\mathrm{Fe}^{2+} \\
\mathrm{Fe}^{3+} \\
\mathrm{Mg \#} \\
\mathrm{Cr} /(\mathrm{Cr}+\mathrm{Al}) \\
\mathrm{Ca} /(\mathrm{Ca}+\mathrm{Na}) \\
\mathrm{K} /(\mathrm{K}+\mathrm{Na})\end{array}$ & $\begin{array}{l}0.19 \\
0.902\end{array}$ & $\begin{array}{l}0.479 \\
0.086 \\
0.521 \\
0.526\end{array}$ & $\begin{array}{l}0.085 \\
0.92\end{array}$ & $\begin{array}{l}0.199 \\
0.899\end{array}$ & $\begin{array}{l}0.534 \\
0.137 \\
0.456 \\
0.544\end{array}$ & $\begin{array}{l}0.544 \\
0.151 \\
0.444 \\
0.579\end{array}$ & $\begin{array}{l}0.111 \\
0.902\end{array}$ & $\begin{array}{l}0.185 \\
0.906\end{array}$ & $\begin{array}{l}0.429 \\
0.03 \\
0.567 \\
0.538\end{array}$ & $\begin{array}{l}0.559 \\
0.383 \\
0.454 \\
0.589\end{array}$ & $\begin{array}{l}0.391 \\
0.049 \\
0.605 \\
0.54\end{array}$ & $\begin{array}{l}0.183 \\
0.906\end{array}$ & $\begin{array}{l}0.362 \\
0.09 \\
0.632 \\
0.542\end{array}$ & $\begin{array}{l}0.315 \\
0.094 \\
0.683 \\
0.508\end{array}$ \\
\hline $\begin{array}{l}\mathrm{Fe}^{3+} /\left(\mathrm{Cr}+\mathrm{Al}+\mathrm{Fe}^{3+}\right) \\
\mathrm{Al} /\left(\mathrm{Cr}+\mathrm{Al}+\mathrm{Fe}^{3+}\right) \\
\mathrm{Cr} /\left(\mathrm{Cr}+\mathrm{Al}+\mathrm{Fe}^{3+}\right)\end{array}$ & & $\begin{array}{l}0.043 \\
0.454 \\
0.503\end{array}$ & & & $\begin{array}{l}0.07 \\
0.424 \\
0.506\end{array}$ & $\begin{array}{l}0.077 \\
0.389 \\
0.535\end{array}$ & & & $\begin{array}{l}0.015 \\
0.455 \\
0.529\end{array}$ & $\begin{array}{l}0.187 \\
0.334 \\
0.479\end{array}$ & $\begin{array}{l}0.025 \\
0.448 \\
0.527\end{array}$ & & $\begin{array}{l}0.046 \\
0.437 \\
0.517\end{array}$ & $\begin{array}{l}0.047 \\
0.468 \\
0.484\end{array}$ \\
\hline
\end{tabular}


Table 3 (continued).

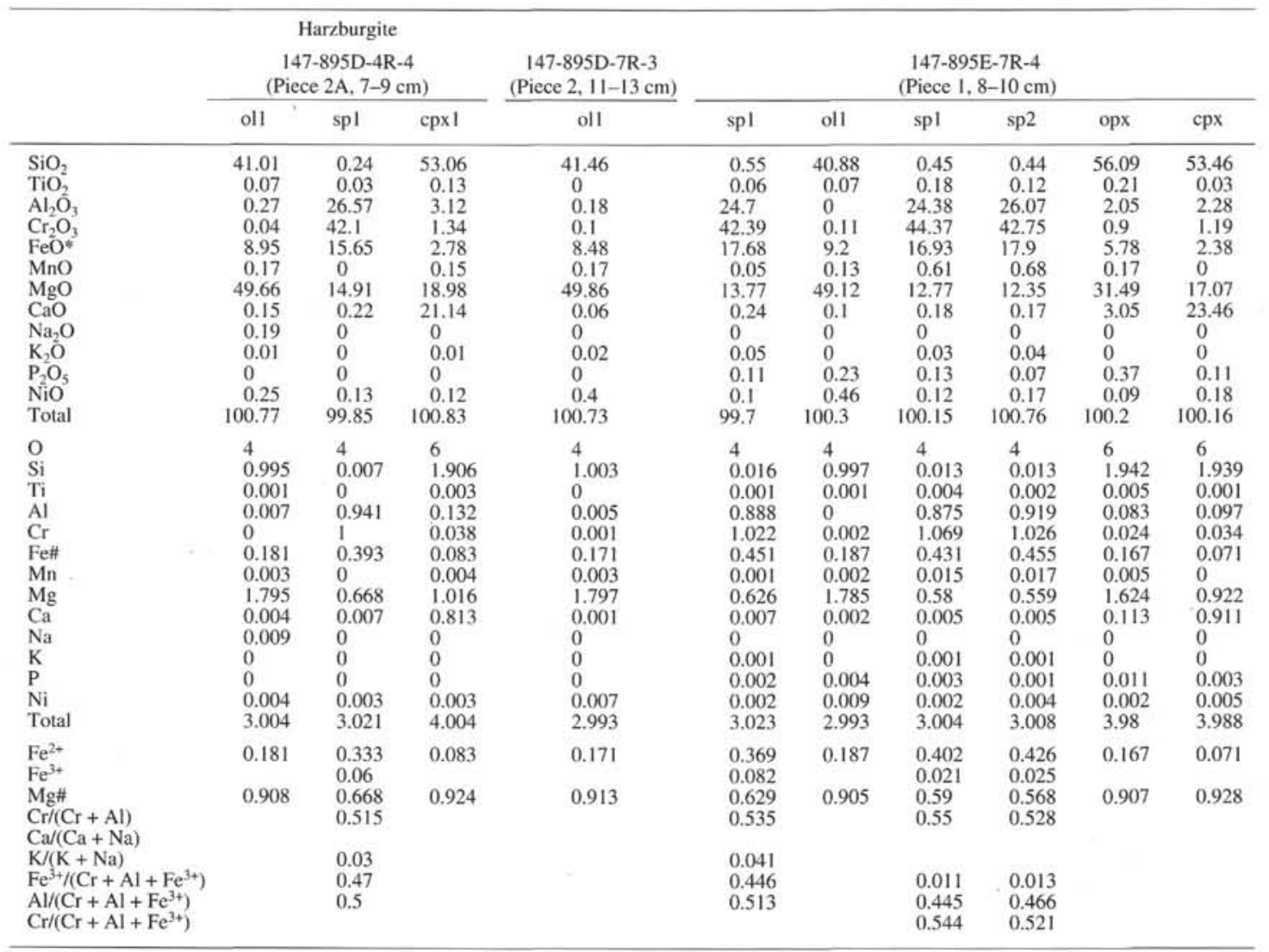


Table 4. Selected microprobe analyses of minerals in chromite pod from Site 895, Hess Deep.

\begin{tabular}{|c|c|c|c|c|c|c|c|}
\hline \multirow[b]{2}{*}{ Chromite pod } & \multicolumn{7}{|c|}{ 147-895E-6R-2 (Piece $5 \mathrm{E}, 77-80 \mathrm{~cm}$ ) } \\
\hline & $\begin{array}{l}\mathrm{sp3}-1 \\
\text { (core) }\end{array}$ & $\begin{array}{l}\text { sp3-2 } \\
\text { (rim) }\end{array}$ & $\begin{array}{c}\mathrm{cpx} \\
\text { (included by chromite) }\end{array}$ & jadeite & amph & opx & plag \\
\hline $\mathrm{SiO}_{2}$ & 0.15 & 0.08 & 52.78 & 58.11 & 45.59 & 57.64 & 68.33 \\
\hline $\mathrm{TiO}^{2}$ & 0.64 & 0.58 & 0.23 & 0.10 & 3.21 & 0.12 & 0.05 \\
\hline $\mathrm{Al}_{2} \mathrm{O}_{3}$ & 25.65 & 26.57 & 3.60 & 25.41 & 10.07 & 0.76 & 19.24 \\
\hline $\mathrm{Cr}_{2} \mathrm{O}_{3}$ & 41.73 & 40.69 & 1.81 & 0.93 & 2.90 & 1.39 & 1.25 \\
\hline $\mathrm{FeO}^{*}$ & 17.31 & 17.43 & 2.64 & 0.39 & 2.68 & 5.12 & 0.49 \\
\hline $\mathrm{MnO}$ & 0.00 & 0.00 & 0.16 & 0.00 & 0.00 & 0.26 & 0.02 \\
\hline $\mathrm{MgO}$ & 15.02 & 15.16 & 17.40 & 0.00 & 17.88 & 34.81 & 0.79 \\
\hline $\mathrm{CaO}$ & 0.13 & 0.15 & 21.91 & 0.34 & 10.34 & 0.61 & 1.19 \\
\hline $\mathrm{Na}_{2} \mathrm{O}$ & 0.00 & 0.00 & 0.24 & 14.71 & 3.97 & 0.00 & 11.00 \\
\hline $\mathrm{K}_{2} \mathrm{O}$ & 0.00 & 0.01 & 0.00 & 0.09 & 0.10 & 0.00 & 0.05 \\
\hline $\mathrm{P}_{2} \mathrm{O}_{5}$ & 0.02 & 0.00 & 0.01 & 0.30 & 0.05 & 0.21 & 0.27 \\
\hline $\mathrm{NiO}$ & 0.27 & 0.31 & 0.00 & 0.07 & 0.11 & 0.06 & 0.01 \\
\hline Total & 100.92 & 100.98 & 100.78 & 100.45 & 96.9 & 100.98 & 102.69 \\
\hline $\mathrm{O}$ & 4 & 4 & 6 & 6 & 23 & 6 & 8 \\
\hline $\mathrm{Si}$ & 0.004 & 0.002 & 1.902 & 1.952 & 6.498 & 1,968 & 2.932 \\
\hline $\mathrm{Ti}$ & 0.014 & 0.013 & 0.006 & 0.002 & 0.343 & 0.003 & 0.001 \\
\hline Al & 0.906 & 0.935 & 0.153 & 1.006 & 1.691 & 0.030 & 0.973 \\
\hline $\mathrm{Cr}$ & 0.989 & 0.961 & 0.051 & 0.025 & 0.327 & 0.037 & 0.042 \\
\hline $\mathrm{Fe}^{*}$ & 0.434 & 0.435 & 0.079 & 0.011 & 0.317 & 0.145 & 0.017 \\
\hline $\mathrm{Mn}$ & 0.000 & 0.000 & 0.004 & 0.000 & 0.000 & 0.007 & 0.000 \\
\hline $\mathrm{Mg}$ & 0.671 & 0.675 & 0.934 & 0.000 & 3.797 & 1.761 & 0.050 \\
\hline $\mathrm{Ca}$ & 0.004 & 0.004 & 0.846 & 0.013 & 1.578 & 0.022 & 0.054 \\
\hline $\mathrm{Na}$ & 0.000 & 0.000 & 0.017 & 0.988 & 1.097 & 0.000 & 0.914 \\
\hline K & 0.000 & 0.000 & 0.000 & 0.004 & 0.018 & 0.000 & 0.003 \\
\hline $\mathrm{P}$ & 0.000 & 0.000 & 0.000 & 0.008 & 0.007 & 0.006 & 0.010 \\
\hline $\mathrm{Ni}$ & 0.006 & 0.007 & 0.000 & 0.002 & 0.012 & 0.001 & 0.000 \\
\hline Total & 3.032 & 3.036 & 3.996 & 4.011 & 15.685 & 3.985 & 4.996 \\
\hline $\mathrm{Fe}^{2+}$ & 0.320 & 0.318 & 0.079 & & & 0.145 & \\
\hline $\mathrm{Fe}^{3+}$ & 0.086 & 0.091 & & & & & \\
\hline Mg\# & 0.677 & 0.680 & 0.922 & & & 0.924 & \\
\hline $\mathrm{Cr} /(\mathrm{Cr}+\mathrm{Al})$ & 0.522 & 0.507 & & & & & \\
\hline $\mathrm{Ca} /(\mathrm{Ca}+\mathrm{Na})$ & & & & & & & 0.056 \\
\hline $\mathrm{K} /(\mathrm{K}+\mathrm{Na})$ & & & & & & & \\
\hline $\mathrm{Fe}^{3+} /\left(\mathrm{Cr}+\mathrm{Al}+\mathrm{Fe}^{3+}\right)$ & 0.044 & 0.046 & & & & & \\
\hline $\mathrm{Al} /\left(\mathrm{Cr}+\mathrm{Al}+\mathrm{Fe}^{3+}\right)$ & 0.457 & 0.471 & & & & & \\
\hline $\mathrm{Cr} /\left(\mathrm{Cr}+\mathrm{Al}+\mathrm{Fe}^{3+}\right)$ & 0.499 & 0.484 & & & & & \\
\hline
\end{tabular}

Notes: Representative analysis is listed for each mineral in all samples examined. If intra- and intergrain heterogeneity was detected, more than two analyses are listed for the mineral. First and second numbers after mineral names indicate intergrain and intragrain points, respectively. Cationic ratios of spinel were calculated assuming spinel stoichiometry after subtracting all $\mathrm{Ti}$ as ulvospinel molecule $\left(\mathrm{Fe}_{2} \mathrm{TiO}_{4}\right)$. Abbreviations for minerals are as follows: ol =olivine; opx $=$ orthopyroxene; $\mathrm{cpx}=\mathrm{Ca}$-rich clinopyroxene; $\mathrm{plag}=\mathrm{plagioclase}$; $\mathrm{sp}=$ chromian spinel; amph = pargasite; $\mathrm{phl}=$ phlogopite, * ${ }^{\mathrm{c} p x 3}=$ mantle; ${ }^{*} \mathrm{opx} \mathrm{I}=\mathrm{core} ;{ }^{*} \mathrm{opx} 2=$ rim of a composite grain in a troctolite $(147-895 \mathrm{C}-4 \mathrm{R}-2-8,141-144 \mathrm{~cm})$. FeO ${ }^{*}$ $=$ total iron as $\mathrm{FeO} ; \mathrm{Fe}^{*}=$ total iron as $\mathrm{Fe} . \mathrm{Fe}^{2+}$ and $\mathrm{Fe}^{3+}=$ number of ferrous and ferric iron cations, respectively, on $\mathrm{O}=4$ for chromian spinel. $\mathrm{Mg} \#=\mathrm{Mg} /\left(\mathrm{Mg}+\mathrm{Fe}{ }^{2+}\right)$ atomic ratio for chromian spinel, and $\mathrm{Mg} /\left(\mathrm{Mg}+\mathrm{Fe}^{*}\right)$ atomic ratio for silicates. 


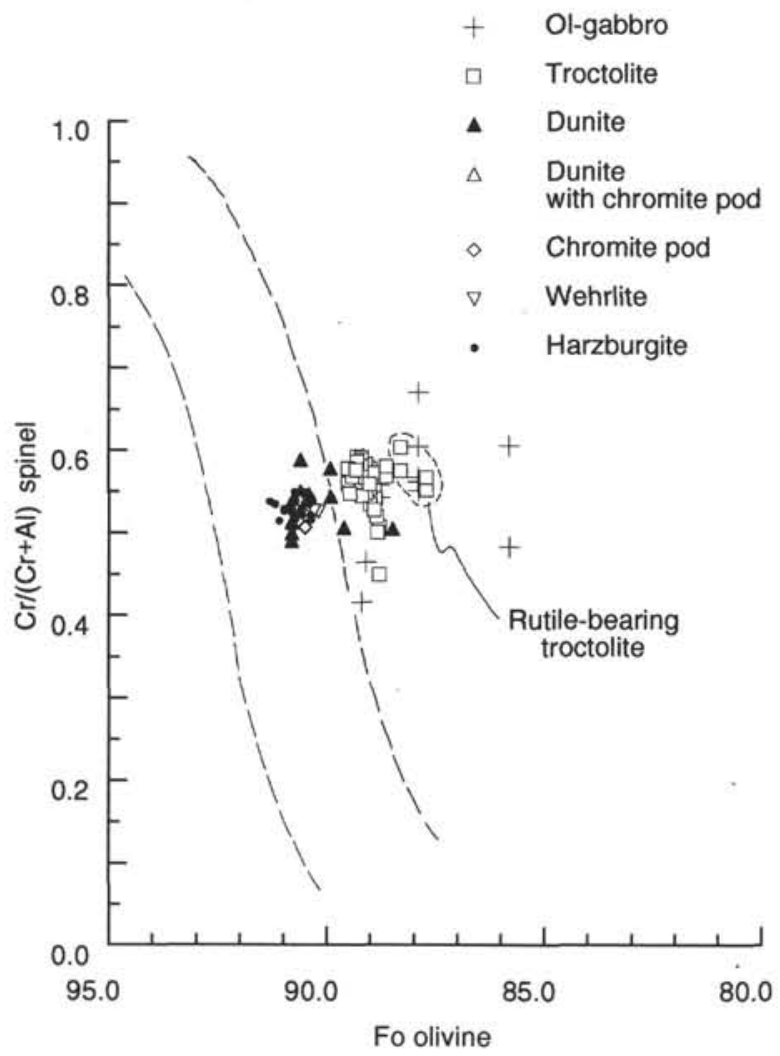

Figure 4. Relationship between Fo of olivine and $\mathrm{Cr} /(\mathrm{Cr}+\mathrm{Al})$ of coexisting chromian spinel in the Hess Deep rocks. The region between the broken lines is the olivine-spinel mantle array, where mantle-derived spinel peridotites plot (Arai, 1994a).

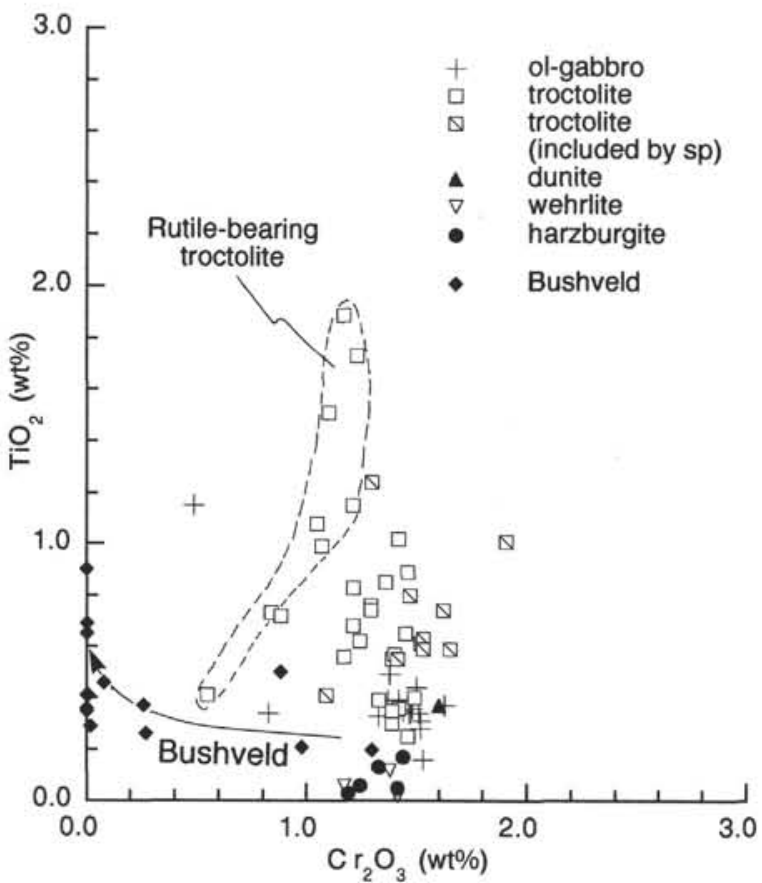

Figure 6. Relationship between $\mathrm{TiO}_{2}$ and $\mathrm{Cr}_{2} \mathrm{O}_{3}$ of clinopyroxene in the Hess Deep rocks. Clinopyroxene from the Bushveld cumulates (Atkins, 1969) is plotted for comparison. (included by $\mathrm{sp}$ ) $=$ inclusion in spinel.

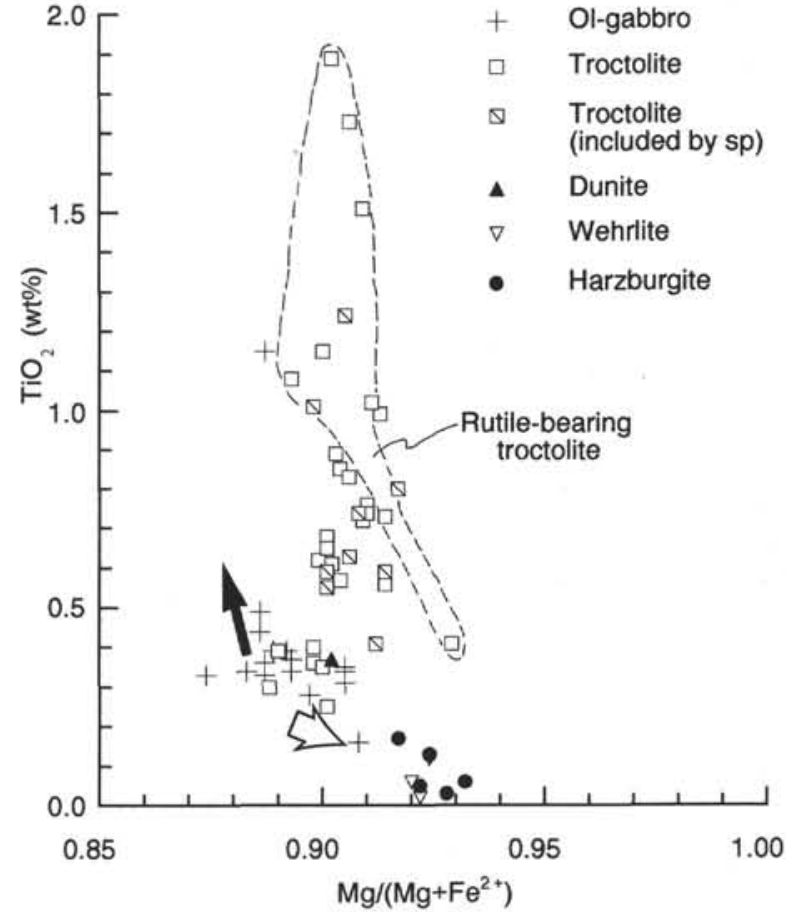

Figure 5. Relationship between $\mathrm{TiO}_{2}$ and $\mathrm{Mg} /\left(\mathrm{Mg}+\mathrm{Fe}^{2+}\right)$ in clinopyroxene in the Hess Deep rocks. The melt should successively precipitate Ti-rich, $\mathrm{Mg}$-poor clinopyroxenes during a simple crystal fractionation (solid arrow), whereas the melt with orthopyroxene dissolution and olivine plus spinel crystallization may successively precipitate $\mathrm{Mg}$-rich, Ti-poor clinopyroxene (open arrow). (included by $\mathrm{sp}$ ) $=$ inclusion in spinel.

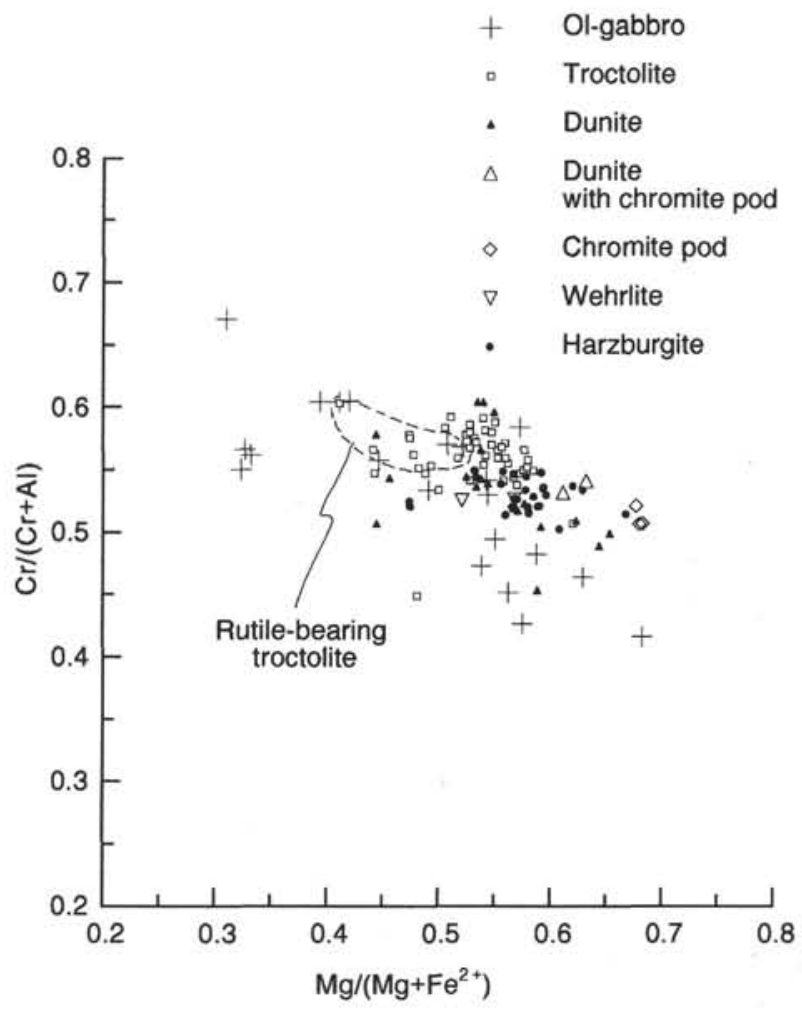

Figure 7. Relationship between $\mathrm{Cr} /(\mathrm{Cr}+\mathrm{Al})$ and $\mathrm{Mg} /\left(\mathrm{Mg}+\mathrm{Fe}^{2+}\right)$ of chromian spinel in the Hess Deep rocks. 


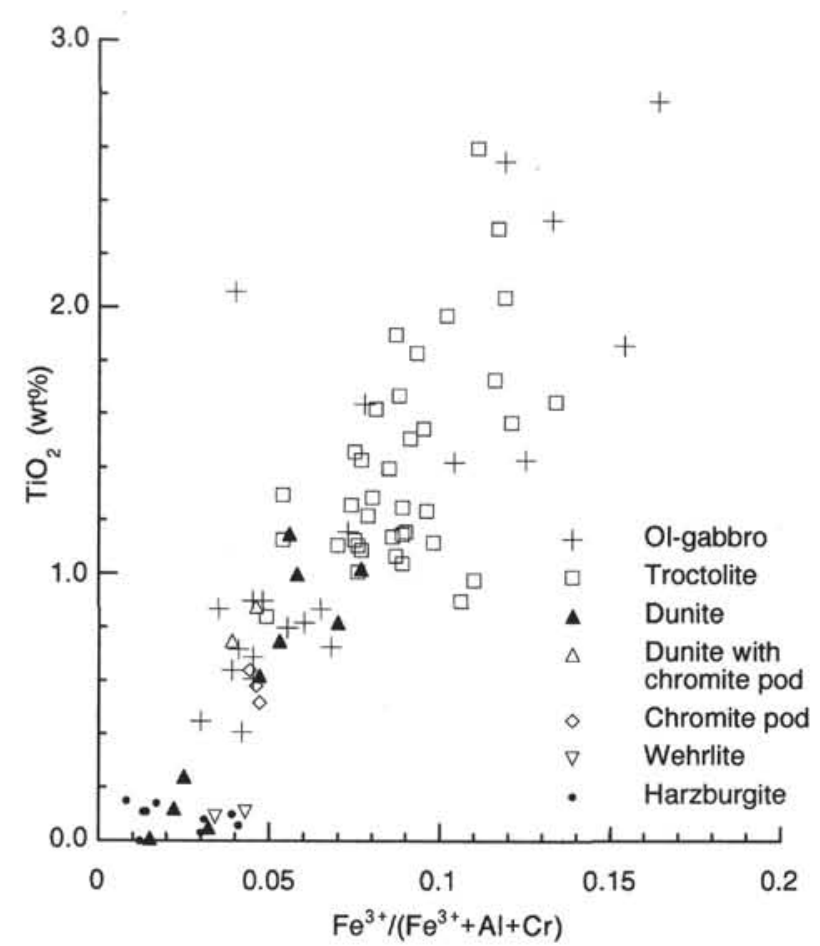

Figure 8. Relationship between $\mathrm{TiO}_{2}$ and $\mathrm{Fe}^{3+}$ atomic ratio of chromian spinel in the Hess Deep rocks.

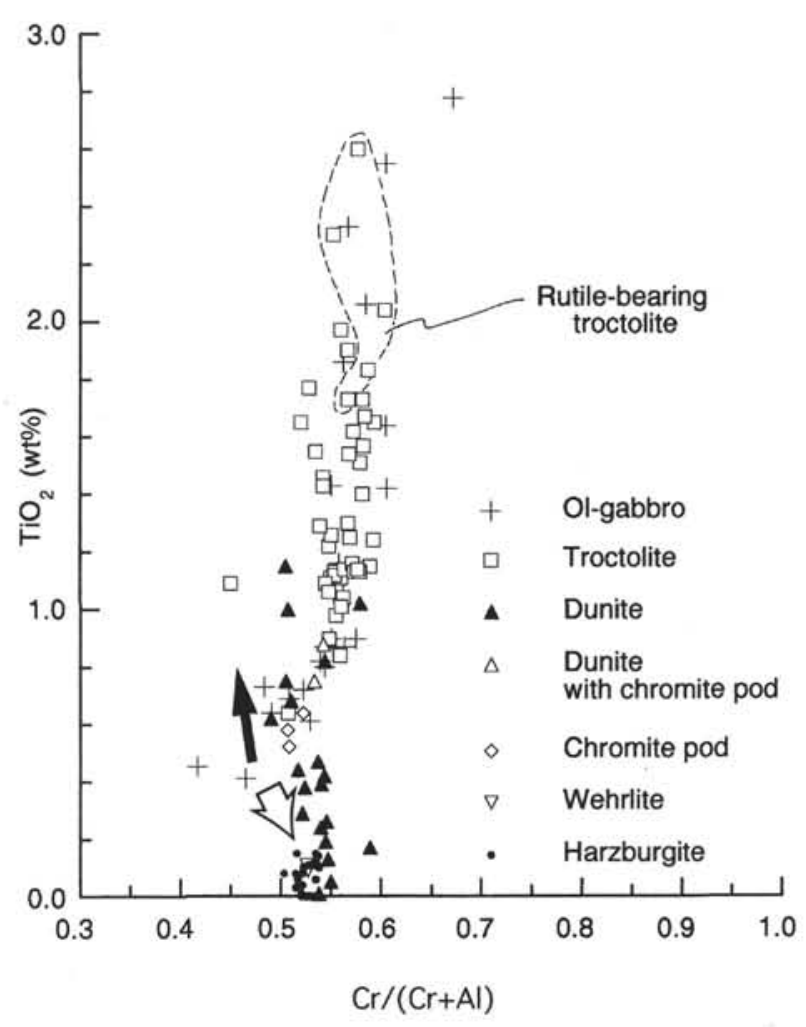

Figure 9. Relationship between $\mathrm{TiO}_{2}$ and $\mathrm{Cr} /(\mathrm{Cr}+\mathrm{Al})$ of chromian spinel in the Hess Deep rocks. The solid arrow shows a possible trend resulting from simple crystal fractionation, whereas the open arrow indicates a possible trend from the dissolution of orthopyroxene and precipitation of olivine plus spinel. 


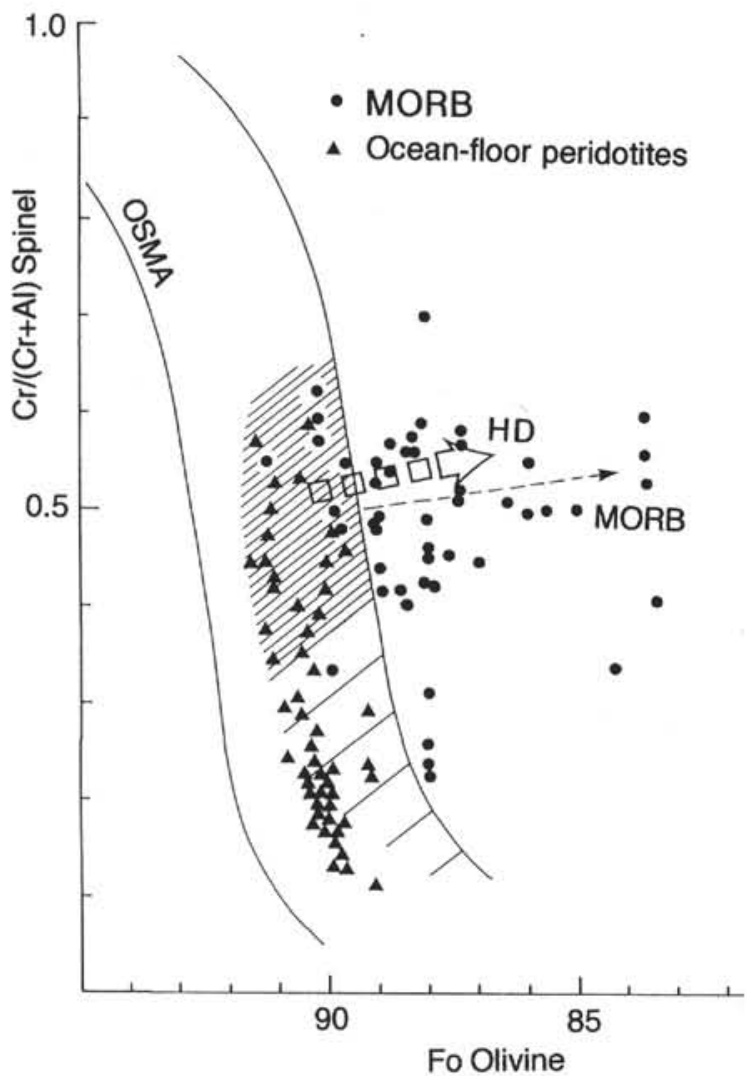

Figure 10. Relationship between $\mathrm{Cr} /(\mathrm{Cr}+\mathrm{Al})$ of spinel and Fo of olivine. MORB, oceanic peridotites, and the "fractionation trend" for MORB (dotted line) are compared with the Hess Deep trend (arrow labeled HD). OSMA indicates the olivine-spinel mantle array (Arai, 1994a). Densely and sparsely hatched areas indicate probable and less probable restites for MORB, respectively.

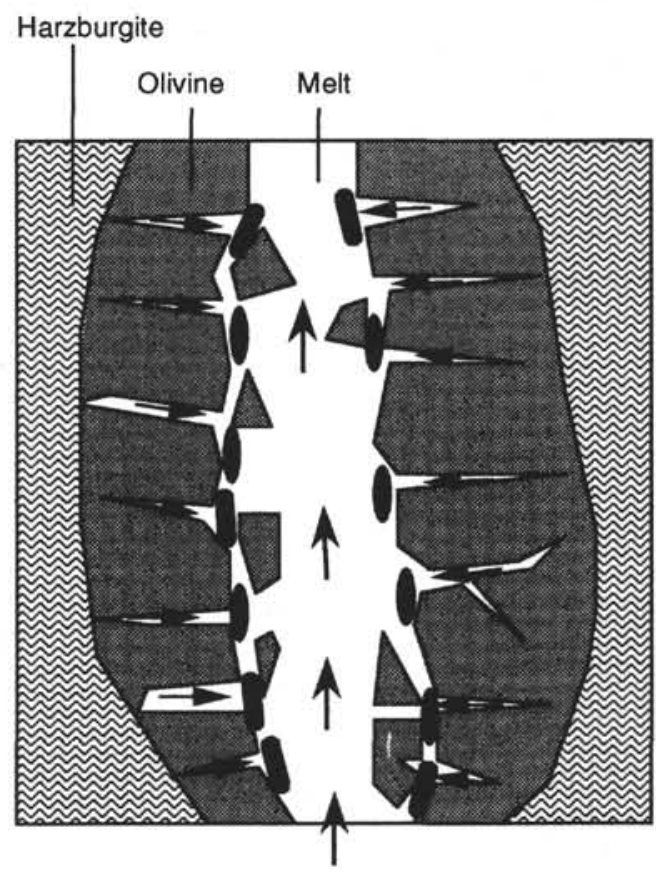

Spinel precipitation

by melt mixing

Secondary melt enriched with $\mathrm{Si}, \mathrm{Cr}, \mathrm{K}, \mathrm{Na}$ and $\mathrm{H} 2 \mathrm{O}$

$\uparrow$

Primitive melt supply

Figure 12. Model for the concentration of chromian spinel in heterogeneous troctolite (see Fig. 2).

Melt slightly stagnated

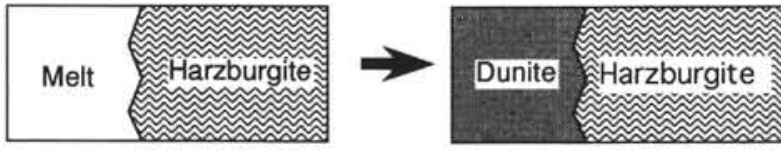

Melt highly stagnated

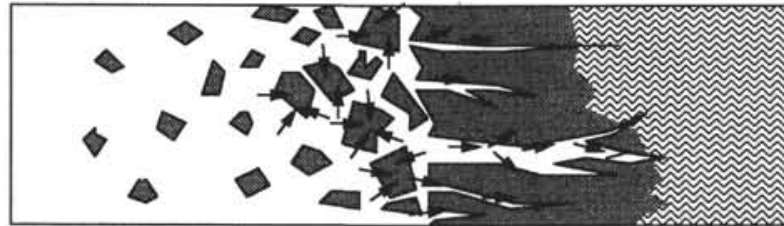

Gabbro Olivine gabbro Troctolite Harzburgite

$\rightarrow$ Ti enrichment

Figure 11. A model for the formation of two kinds of dunite by mantle-melt interaction: plagioclase-free dunite with a low-Ti mineralogy and plagioclase-bearing dunite with high-Ti mineralogy. The former dunite forms if the involved melt is slightly stagnated, whereas the latter one forms if the melt is highly stagnated. Ti enrichment occurs in the frontal zone of interaction, where highly evolved melt is involved. 

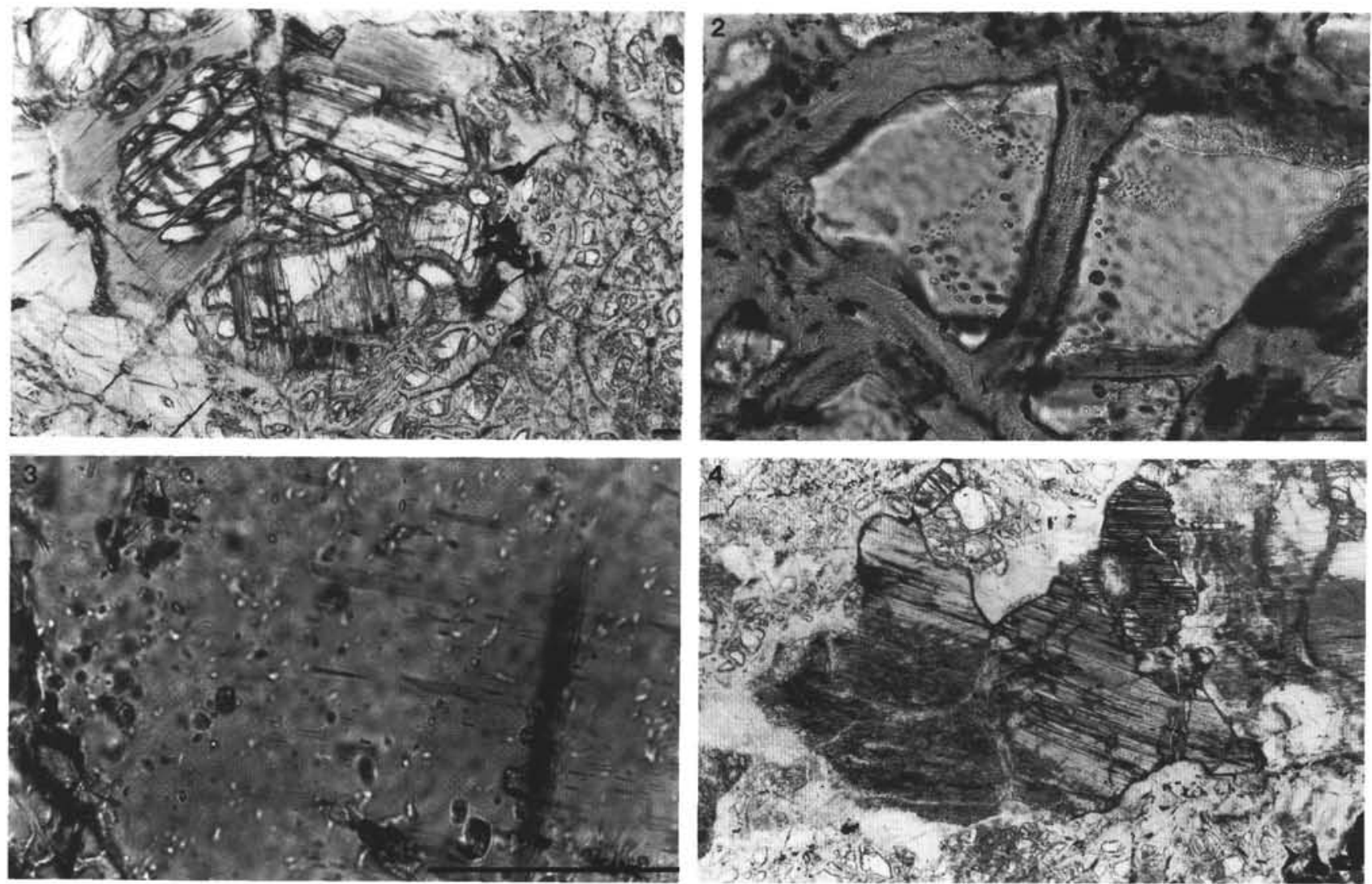

Plate 1. Photomicrographs and an SEM micrograph of the Hess Deep rocks from Hole 895. Plane-polarized light and scale bar $=0.1 \mathrm{~mm}$, if not otherwise indicated. 1. Harzburgite (Sample 147-895E-7R-4, [Piece 1, 8-10 cm]) with a weak porphyroclastic texture. Note that the orthopyroxene is crystallized into several grains. Chromian spinel, at center right, is highly anhedral. 2. Inclusion trains in olivine in plagioclase-free dunite (Sample 147-895C-4R-3 [Piece 4, 41-43 $\mathrm{cm}])$. Scale bar $=0.05 \mathrm{~mm}$. 3. Olivine with lamellar inclusions of spinel in plagioclase-free dunite (Sample 147-895C-4R-3 [Piece 4, 41-43 cm]). Scale bar $=$ $0.05 \mathrm{~mm}$. 4. Clinopyroxene in a possible wehrlite (Sample 147-895C-3R-1 [Piece 22, 130-133 cm]). Note the large size of the clinopyroxene. 5. SEM micrograph of chromian spinel with a sieve texture in the chromitite pod (Sample 147-895E-6R-2 [Piece 5E, 77-80 cm]) (Fig. 3). Scale bar = 1 mm. 6. Kinked olivine in a heterogeneous troctolite (Sample 147-895C-4R-2 [Piece 6B, 110-114 cm]). Cross-polarized light. 7. Subhedral chromian spinel in an olivine clot from a heterogeneous troctolite (Sample 147-895C-4R-2 [Piece 6B, 110-114 cm]). Note that the spinel is free of mineral inclusions. 8. Anhedral chromian spinel in an olivine-poor part of a heterogeneous troctolite (Sample 147-895C-4R-2 [Piece 6B, 110-114 cm]). Note that the spinel has rounded mineral inclusions. 9. Polymineralic inclusions in chromian spinel of a heterogeneous troctolite (Sample 147-895C-4R-2 [Piece 6B, 110-114 cm]). 10. Orthopyroxene (O) rimmed by clinopyroxene $(C)$ in olivine-rich dunitic troctolite (Sample 147-895C-4R-2 [Piece 8, 141-144 cm]). The boundary between the pyroxenes is highlighted by a dashed line. 11. Rutile and kaersutite $(\mathrm{K})$ in olivine-rich troctolite (Sample 147-895C-4R-2 [Piece 1B, 36-41 cm]). 12. Clinopyroxene that poikilitically includes plagioclase in olivine gabbro (Sample 147-895D-7R-1 [Piece 6, 36-40 cm]). 

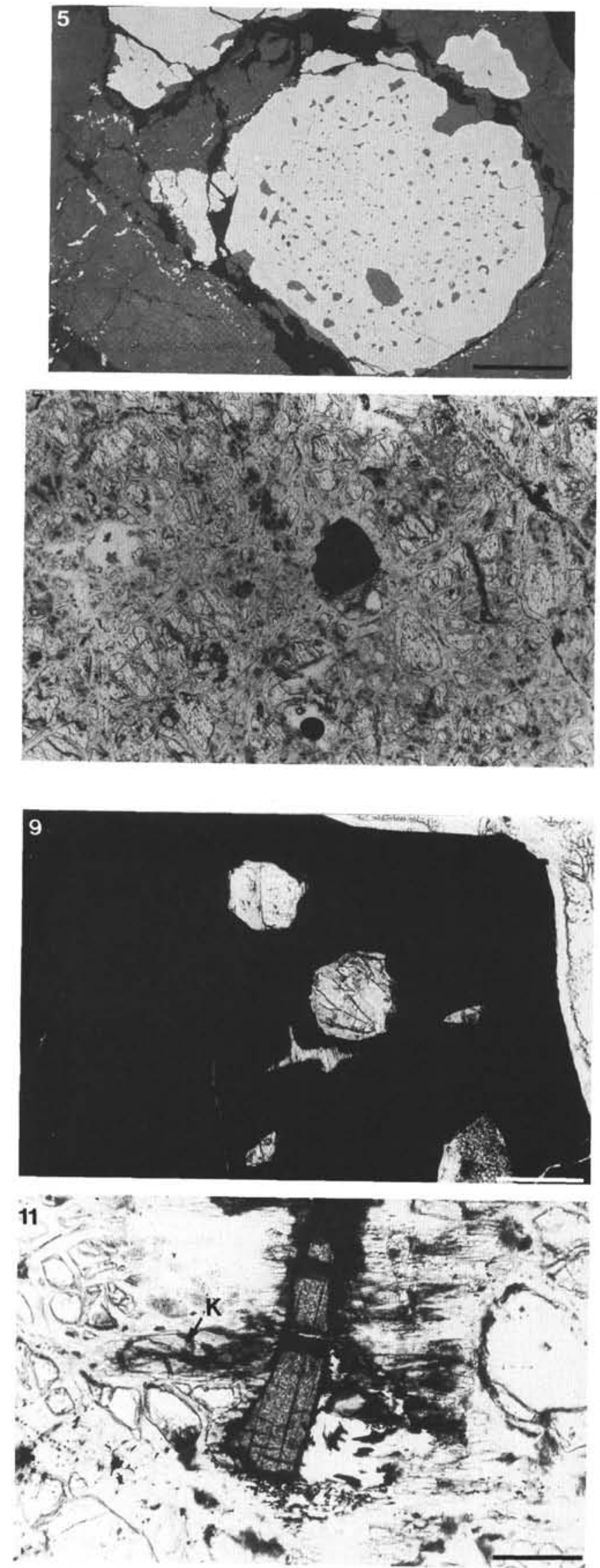
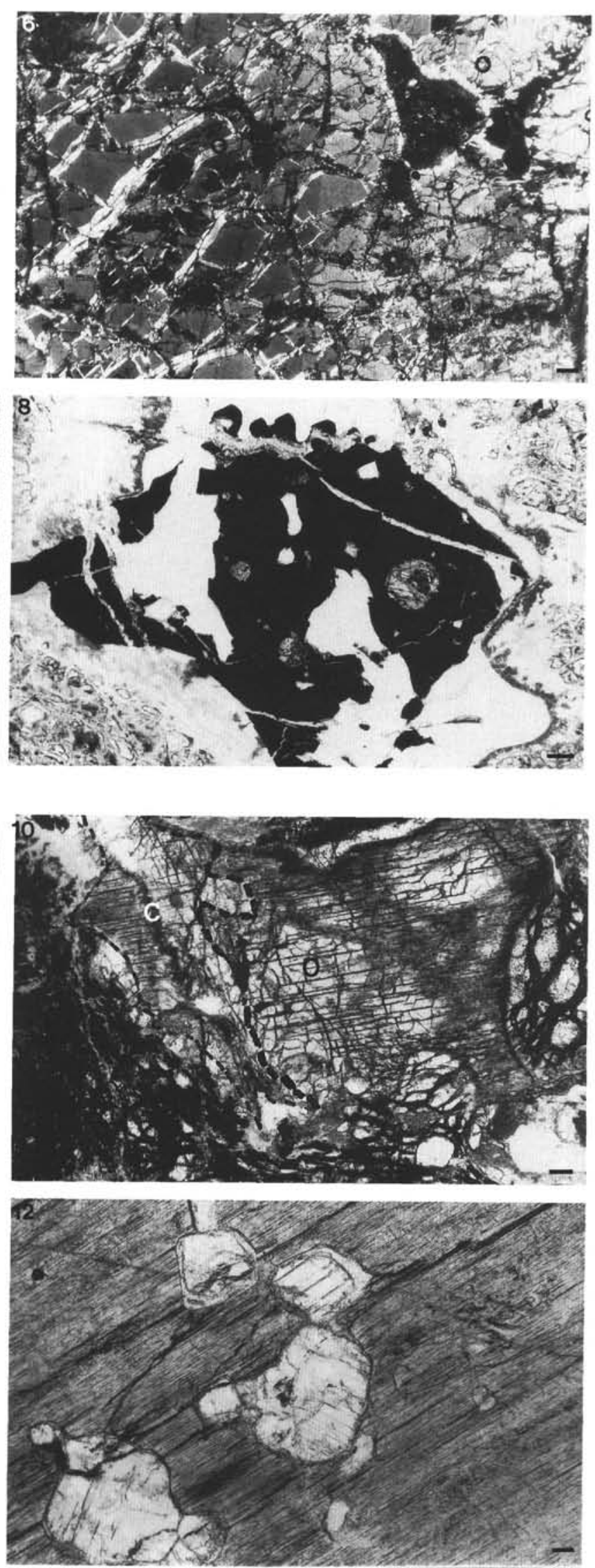

Plate 1 (continued). 